


\section{Advies over de geschiktheid van de alpaca als productiedier}

Francesca Neijenhuis

Marko Ruis

Martien Bokma

Dit onderzoek is uitgevoerd door Wageningen Livestock Research, in opdracht van en gefinancierd door het Ministerie van Landbouw, Natuur en Voedselkwaliteit, in het kader van het Beleidsondersteunend onderzoek thema Dierenwelzijn (projectnummer BO-20-008-004.37; KvB-2014 007)

Wageningen Livestock Research

Wageningen, december 2015

Rapport 928 
Francesca Neijenhuis, Marko Ruis en Martien Bokma, 2015. Advies over de geschiktheid van de alpaca als productiedier. Wageningen, Wageningen Livestock Research, Rapport 928.

\section{Samenvatting NL}

Advies over de geschiktheid van de alpaca als productiedier, aan de hand van literatuurscan, bedrijfsaudit en expertview. In principe is de alpaca geschikt om te houden als productiedier, mits aan een aantal voorwaarden op het gebied van o.a. bezettingsgraad, schuilmogelijkheden, zandbaden en specifieke alpacakennis wordt voldaan.

\section{Summary UK}

Advice on the suitability of the alpaca (Vicugna pacos) as a production animal, on the basis of literature scan, farm audit and extert view. In principle, the alpaca is suitable as production animal, provided that a number of conditions in the field of, among others, animal density, shelters, sand baths and specific alpaca knowledge are met.

Dit rapport is gratis te downloaden op https://doi.org/10.18174/468584 of op www.wur.nl/livestock-research (onder Wageningen Livestock Research publicaties).

\section{(C) 2015 Wageningen Livestock Research}

Postbus 338, 6700 AH Wageningen, T 03174839 53, E info.livestockresearch@wur.nl, www.wur.nl/livestock-research. Wageningen Livestock Research is onderdeel van Wageningen University \& Research.

Wageningen Livestock Research aanvaardt geen aansprakelijkheid voor eventuele schade voortvloeiend uit het gebruik van de resultaten van dit onderzoek of de toepassing van de adviezen.

Alle rechten voorbehouden. Niets uit deze uitgave mag worden vermenigvuldigd en/of openbaar gemaakt worden door middel van druk, fotokopie, microfilm of op welke wijze dan ook zonder voorafgaande toestemming van de uitgever of auteur.

Wageningen Livestock Research is NEN-EN-ISO 9001:2015 gecertificeerd. Op al onze onderzoeksopdrachten zijn de Algemene Voorwaarden van de Animal Sciences Group van toepassing. Deze zijn gedeponeerd bij de Arrondissementsrechtbank Zwolle. 


\section{Inhoud}

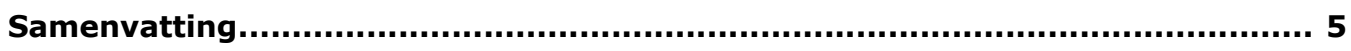

1

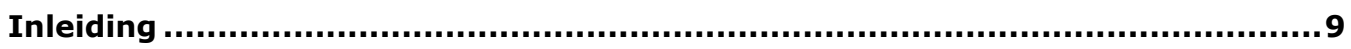

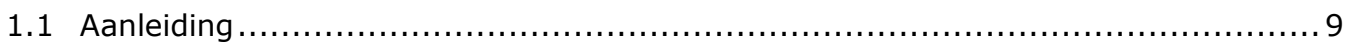

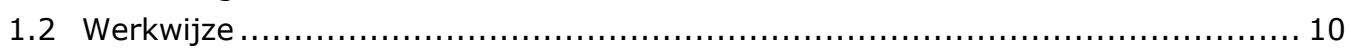

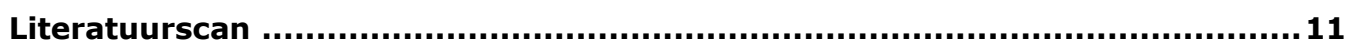

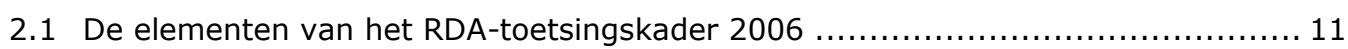

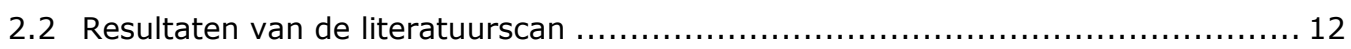

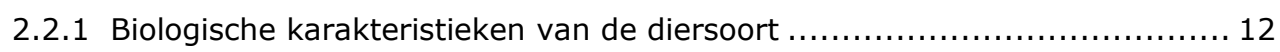

2.2.2 Algemene informatie met betrekking tot het houden van de betreffende

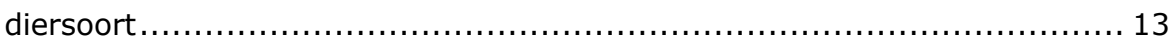

2.2.3 Specifieke welzijnseisen met betrekking tot het houden van de betreffende

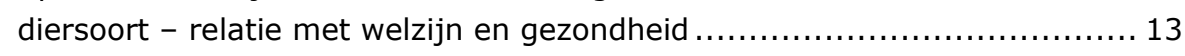

2.2.4 Doel waartoe de diersoort gehouden wordt ................................ 19

2.2.5 Ervaringen van elders met het houden van de betreffende diersoort. ........ 19

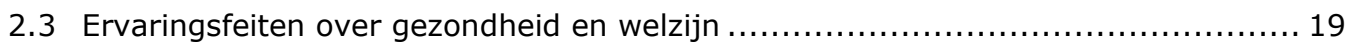

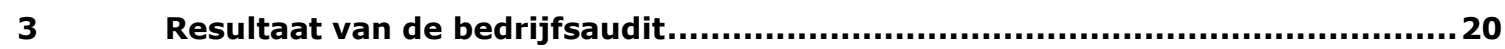

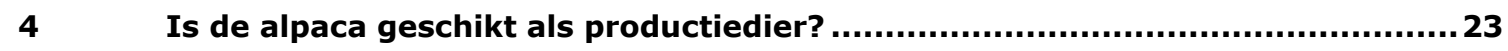

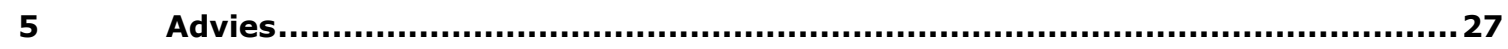

Literatuur......................................................................................... 28

Bijlage 1 Besluit Houders van Dieren: aanwijzing productiedieren...................32

Bijlage 2 Toetsingskader voor het verlenen van ontheffing voor diersoorten die niet bij algemene maatregel van bestuur t.b.v. artikel 34 GWWD zijn

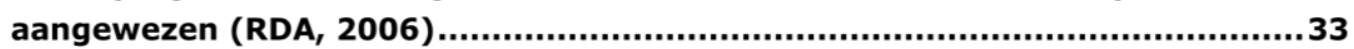

Bijlage 3 Definitie Ernst, Duur en Omvang uit Ongeriefanalyse ........................34 



\section{Samenvatting}

De directie Dierlijke Agroketens en Dierenwelzijn (DAD) van het ministerie van Economische Zaken heeft aan Wageningen Livestock Research het volgende gevraagd:

Advies aan de hand van het door de RDA opgestelde toetsingskader (RDA 2006/08) over de geschiktheid van de alpaca als productiedier, rekening houdend met diergezondheid en dierenwelzijn en warin indien van toepassing tevens randvoorwaarden zijn opgenomen waarmee het risico op diergezondheidsproblemen en/of dierenwelzijnsproblemen kan worden geminimaliseerd.

Het toetsingskader van de RDA (2006/08) voor de toelaatbaarheid van het houden van diersoorten voor productiedoeleinden was leidend voor beantwoording van de adviesvraag. Ter onderbouwing van een advies is een beknopte literatuurscan uitgevoerd naar de gezondheid en het welzijn van bedrijfsmatig gehouden alpaca's; is bij de aanvragende alpacahouder vooraf bedrijfsinformatie opgevraagd bij de onderdelen van het RDA-format; en is door drie dieronderzoekers van WUR en een gespecialiseerd dierenarts een bedrijfsaudit uitgevoerd. Hierbij is een algemene indruk verkregen van het bedrijf en zijn de houderijomstandigheden, dierenwelzijn en diergezondheid gescoord aan de hand van vooraf opgestelde indicatoren. Op basis van de literatuurscan, het bedrijfsdossier en de bevindingen tijdens de bedrijfsaudit en aangevuld met expertview is een advies uitgewerkt over de geschiktheid van de alpaca als productiedier, en zijn randvoorwaarden benoemd waaronder geconstateerde risico's op diergezondheid- en/of dierenwelzijnsproblemen kunnen worden geminimaliseerd.

\section{Wordt voldaan aan geldende wet- en regelgeving?}

Alpaca's lijken regelmatig bij slachthuizen ter slacht te worden aangeboden, zowel door het beoordeelde bedrijf als door andere alpacahouders in Nederland. Aangezien de alpaca (nog) niet is aangewezen als productiedier is het slachten ervan strijdig met de geldende regelgeving. Het beoordeelde bedrijf geeft aan op dit moment toestemming te hebben van de Nederlandse Voedsel- en Warenautoriteit (NVWA) om overtollige alpaca's als 'harig wild' te laten slachten door een daartoe bevoegde slachter.

Fysieke beoordeling van het transport naar en het verdoven en doden op het slachthuis maakte geen onderdeel uit van de bedrijfsaudit. Hierover kunnen wij derhalve geen onderbouwde uitspraken doen. Navraag bij de zelf slachtende slager leert dat de alpaca's werden verdoofd met een penetrerend schietmasker ( 0.22 slagpen met groene patronen (lichte lading, bestemd voor varkens, kalveren, schapen)). Na controle op een correcte bedwelming (oogreflex, ademhaling, etc.) werd binnen 30 sec de halssnede gezet. De positie van het schietmasker was conform de aanbeveling van Gibson et al. (2015).

\section{In hoeverre wordt welzijn en gezondheid geschaad? Wat is de ernst ervan?}

Potentiele welzijnsknelpunten bij het (extensief) houden van alpaca's hangen onder andere samen met te natte weiden en het ontbreken van droge sta- en ligplekken in stallen (risico op o.a.

voetzoolaandoeningen); de afwezigheid van de mogelijkheid om te zandbaden; onvoldoende kwaliteit van voeding en stro; en een te hoge bezetting. Daarnaast stellen alpaca's specifieke eisen aan de verzorging. Impulsaankopen zijn om die reden ongewenst.

Op het bedrijf zijn er op het moment van de bedrijfsaudit geen belangrijke welzijns- of gezondheidsproblemen waargenomen. Het geauditeerde bedrijf voldoet op dit moment (ruimschoots) aan de genoemde voorwaarden voor het minimaliseren van het risico op gezondheids- en welzijnsproblemen. 


\section{Onderscheiden marktwaarde en dierenwelzijn}

Alpaca's worden (bedrijfsmatig) in het buitenland vooral gehouden voor de productie van de wol, waarbij de uitstootdieren voor de vleesconsumptie kunnen worden gebruikt. De twee alpaca-fenotypen produceren een verschillende kwaliteit wol. Huacaya's produceren een dichte, zachte, krullerige, schaapachtige vezel; de Suri's produceren zijdeachtige, lange vezels, die enigszins op dreadlocks lijken. De wol van de Suri's brengt het meeste op. Naast wol opbrengsten kunnen er inkomsten zijn uit verkoop van goede fokdieren, verkoop van dieren met een mindere kwaliteit wol/exterieur aan hobbydierhouders en eventueel verkoop van vlees van overtollige dieren (op dit moment is slachten in Nederland niet toegestaan). Het vlees van de alpaca heeft een laag vet- en cholesterolpercentage. Ook op andere vleeskwaliteitsparameters scoort alpacavlees gunstig. Alpaca's zijn een belangrijke vleesbron voor bewoners van het Andes-gebergte. Daarnaast is er een toenemende vraag naar vlees van alpaca's en vooral lama's in rijkere landen vanwege het lage vet- en cholesterolgehalte. Tegenover het doel van de productie op het beoordeelde bedrijf (wol, verkoop van fok- en gebruiksdieren, en de mogelijkheid om niet-plaatsbare overtollige dieren te laten slachten voor het vlees) staan, naast diverse positieve aspecten voor dierenwelzijn, enkele als gering gescoorde welzijnsaantastingen. In hoeverre het productiedoel qua nut en noodzaak opweegt tegen deze geringe welzijnsaantastingen vraagt om een ethisch/politieke afweging en valt buiten het bestek van de adviesopdracht.

\section{Zijn er voldoende mogelijkheden voor het goed managen van het houden van de alpaca om (risico op) diergezondheids- en/of dierenwelzijnsproblemen te minimaliseren?}

Op basis van de literatuurscan en de uitgevoerde bedrijfsaudit zijn we van mening dat er in principe voldoende mogelijkheden zijn voor het goed managen van het houden van de alpaca als productiedier, mits aan een aantal voorwaarden wordt voldaan om het risico op welzijns- en gezondheidsproblemen te minimaliseren:

$>$ Voor het houden van alpaca's is alpaca-specifieke kennis nodig bij houder en dierenarts.

$>$ Houd de bezettingsgraad laag, zorg dat de dieren over voldoende oppervlakte weide en stal beschikken. De adviezen hierover lopen uiteen en zijn afhankelijk van wel of niet bijvoeren van de dieren en de wijze van beheersing van parasitaire infecties (van circa $40 \mathrm{~m}^{2}$ per dier (Zwitserse Dierenbescherming; met bijvoedering) via circa $120 \mathrm{~m}^{2}$ per dier (Duitse literatuur) tot $570 \mathrm{~m}^{2}$ per dier (Noord-Amerika; geen bijvoedering)). Alpaca's zijn uitgesproken kuddedieren en dienen niet individueel te worden gehouden in weide/stal (minimaal 2 dieren bij elkaar).

$>$ Voorkom via managementmaatregelen het ontstaan van voetzoollaesies bij de dieren. Zorg dat alle dieren op ieder moment de beschikking hebben over een overdekte schuilmogelijkheid, waarin ze droog kunnen staan en liggen. Zorg dat dieren niet op natte en modderige weides hoeven te staan.

> Zorg voor de aanwezigheid van een 'zandbak', een plek waarin de dieren kunnen zandbaden om de noodzakelijke vachtverzorging uit te voeren.

$>$ Vervoer dieren bij transport niet-aangebonden en met meerdere dieren tegelijk.

Uit recente literatuur (Gibson et al., 2015) komt naar voren dat het verdoven van alpaca's voorafgaand aan doden/slachten effectief kan plaatsvinden met een penetrerend schietmasker (paarse 2,5 grams slagpen, kruitlading $190 \mathrm{mg}$ ). De top-of-the-head positie van het schietmasker (op de kruin) is daarbij de beste positie, en heeft de voorkeur boven de frontale positie.

\section{Advies}

Op het moment van de audit van het alpacabedrijf zijn er geen belangrijke welzijns- of gezondheidsproblemen waargenomen. Het geauditeerde bedrijf voldoet (ruimschoots) aan de genoemde voorwaarden voor minimaliseren van het risico op gezondheids- en welzijnsproblemen.

Specifieke beoordeling van welzijnsindicatoren tijdens transport en bij het verdoven/doden op het slachthuis maakte geen onderdeel uit van de bedrijfsaudit. Hierover kunnen wij derhalve geen onderbouwde uitspraken doen. In een recent Brits onderzoek naar bedwelmen van alpaca's met een penetrerend schietmasker wordt een aanbeveling gedaan om in de procedure op te nemen wat de 
positie van het masker zou moeten zijn. Tevens concluderen zij dat een adequate fixatie van het hoofd-/nekgebied, waarbij het dier zo min mogelijk stress ondervindt, de accuraatheid van het schot verder zou kunnen verbeteren. Dit onderzoek (Gibson et al. 2015) zou van waarde kunnen zijn om de huidige Nederlandse manier van verdoven van alpaca's aan te toetsen en waar nodig te verbeteren.

NB. Onze beoordeling van de geschiktheid van de alpaca als productiedier is uitgevoerd in het licht van de bedrijfsomstandigheden waaronder de alpaca's op het geauditeerde bedrijf op extensieve wijze worden gehouden, met continu en jaarrond weidegang. 


\section{$1 \quad$ Inleiding}

\section{$1.1 \quad$ Aanleiding}

Het is in Nederland verboden om dieren te houden met het oog op de van die dieren afkomstige producten, tenzij de diersoort of -categorie hiertoe is aangewezen en staat vermeld op bijlage II behorende bij art. 2.1 van het Besluit Houders van Dieren (de lijst van productiedieren).

De alpaca (Vicugna pacos; eerder Lama pacos) wordt in Nederland en de ons omringende landen in toenemende mate gehouden als gezelschapsdier, voor de fokkerij en/of met het oog op de wol- en/of vleesproductie. De alpaca staat als soort niet vermeld op de lijst van productiedieren (zie bijlage 1 ). In 2009 heeft de Nederlandse Voedsel- en Warenautoriteit (NVWA) gesteld dat alpacawol overeenkomstig Verordening (EG) nr. 1774/2002 kan worden bestemd als dierlijk bijproduct vallend binnen categorie 3: dergelijke wol kan overeenkomstig de bepalingen worden verwerkt in een daartoe erkende inrichting. De NVWA gaf daarbij aan dat van een verbod op het handelsverkeer in dergelijke wol op basis van de op dat moment van kracht zijnde Gezondheids- en Welzijnswet voor Dieren geen sprake (meer) kon zijn. Hieruit valt af te leiden dat het houden van alpaca's ten behoeve van de wol derhalve lijkt te zijn toegestaan, ook al staat de alpaca niet als soort vermeld op de lijst van productiedieren behorend bij art. 2.1 van het Besluit houders van dieren. Het houden van alpaca's voor recreatieve doeleinden (kinderboerderij of particulier) is eveneens toegestaan. Het houden van alpaca's voor vleesproductie is op dit moment niet toegestaan.

In het verleden zijn door diverse alpacahouders al af en toe dieren ter slacht aangeboden en ook daadwerkelijk geslacht. Bij navraag bij de NVWA blijkt dat de alpaca volgens de Verordening (EG) 853/2004 bijlage I (punten 1.6 en 1.2) onder de definitie valt van "gekweekt wild". Het slachten van alpaca's valt daarmee onder het toepassingsbereik van de Vo 1099/2009 (zie art 1 lid1). Dat wil zeggen dat bedwelming is toegestaan met de methoden genoemd in bijlage I van die verordening. Het probleem is dat de alpaca weliswaar volgens de Vo 1099/2009 een productiedier is (of in ieder geval kan zijn), maar dat onze nationale regels het slachten van een alpaca niet toe staan, omdat deze soort niet is aangewezen als productiedier op grond van het Besluit Houders van Dieren.

De NVWA heeft aan een alpacahouder in Nederland eind 2013 gemeld dat dit slachten vanaf 1-1-2014 niet meer mogelijk zou zijn. De alpacahouder heeft vervolgens middels een telefoongesprek en brief d.d. 13-12-2013 het ministerie van Economische Zaken (EZ) verzocht om een formele mogelijkheid te creëren dat overtollige alpaca's kunnen worden geslacht. Met als argumentatie dat alpacavlees in Zuid-Amerika al honderden jaren wordt geconsumeerd; alpaca's ook in Nederland in steeds grotere getale aanwezig zijn en gesleep met (overtollige) dieren naar buitenlandse slachthuizen moet worden voorkomen. Onder overtollige dieren vallen onder andere dieren die gebreken krijgen (ouderdom, blijvende kreupelheid, vruchtbaarheidsproblemen e.d.) en dieren die ongeschikt zijn voor de fokkerij en ongeschikt voor verkoop aan hobbyhouders.

Naar aanleiding van dit verzoek heeft de directie Dierlijke Agroketens en Dierenwelzijn (DAD) van het ministerie van EZ aan WUR het volgende gevraagd:

Advies aan de hand van het door de RDA opgestelde toetsingskader (RDA 2006/08) over de geschiktheid van de alpaca als productiedier, rekening houdend met diergezondheid en dierenwelzijn en waarin indien van toepassing tevens randvoorwaarden zijn opgenomen waarmee het risico op diergezondheidsproblemen en/of dierenwelzijnsproblemen kan worden geminimaliseerd.

Dit rapport bevat de onderbouwing en formulering van het gevraagde advies. 


\subsection{Werkwijze}

Het toetsingskader van de RDA (2006/08) voor de toelaatbaarheid van het houden van diersoorten voor productiedoeleinden was leidend voor beantwoording van de onderzoeksvraag (zie bijlage 2).

Ter onderbouwing van een advies zijn de volgende activiteiten uitgevoerd:

1. Er is een beknopte literatuurscan uitgevoerd van wetenschappelijke literatuur in binnen- en buitenland in relatie met de verschillende elementen van het RDA-toetsingskader over de gezondheid en het welzijn van bedrijfsmatig gehouden alpaca's. Hierbij is wetenschappelijke literatuur over (potentiële) risico's op basis van natuurlijk gedrag en ervaringsfeiten over de gezondheid en het welzijn van alpaca's onder de voorkomende houderijomstandigheden samengevat. Uit de literatuurscan zijn belangrijke aandachtspunten voor de navolgende bedrijfsaudit gehaald.

2. Bij de houder van de alpaca's die het verzoek bij EZ heeft ingediend is voorafgaand aan het bedrijfsbezoek bedrijfsinformatie opgevraagd en ontvangen over de verschillende onderdelen van het RDA-toetsingskader.

3. Op het bedrijf is door drie dieronderzoekers en een dierenarts met specialistische kennis over kameelachtigen en alpaca's een bedrijfsaudit uitgevoerd. De alpacahouder heeft hier alle gelegenheid voor gegeven. Hierbij is een algemene indruk verkregen van het bedrijf en zijn de houderijomstandigheden, dierenwelzijn en diergezondheid gescoord aan de hand van vooraf opgestelde indicatoren. De Welfare Quality ${ }^{\circledR}$ systematiek (Blokhuis et al., 2013), een Europees gedragen systematiek voor het meten van dierenwelzijn, grotendeels op basis van kenmerken van en metingen aan dieren, heeft model gestaan voor het auditformulier. De bevindingen tijdens de bedrijfsaudit zijn vastgelegd in het auditformulier (bijlage 2). Op basis van de literatuurscan, het bedrijfsdossier en de bevindingen tijdens de bedrijfsaudit en aangevuld met expertview is een advies uitgewerkt over de geschiktheid van de alpaca als productiedier en zijn randvoorwaarden benoemd waaronder geconstateerde risico's op diergezondheid- en/of dierenwelzijnsproblemen kunnen worden geminimaliseerd. 


\section{Literatuurscan}

\subsection{De elementen van het RDA-toetsingskader 2006}

De literatuurscan is uitgewerkt volgens het RDA toetsingskader 2006. Volgens dit toetsingskader dient, voor het verlenen van ontheffing voor diersoorten die niet bij algemene maatregel van bestuur t.b.v. artikel 34 GWWD (thans art. 2.1 Besluit Houders van Dieren) zijn aangewezen, de onderstaande informatie te worden verstrekt en conclusies te worden getrokken.

\section{Informatie dient te worden verstrekt op de volgende punten:}

1. Biologische karakteristieken van de diersoort - het betreft inzicht in de soortspecifieke eigenschappen van de alpaca en diens natuurlijke leefomgeving;

2. Algemene informatie met betrekking tot het houden van de betreffende diersoort - algemene eisen die aan het houden van alpaca's moeten worden gesteld;

3. Specifieke welzijnseisen met betrekking tot het houden van de betreffende diersoort - hier dient puntsgewijs te worden ingegaan op de specifieke gezondheids- en welzijnseisen die aan het houden van de dieren zijn verbonden. Specifiek voor de alpaca zijn de volgende items van het RDA-toetsingskader relevant:

- Huisvestingseisen voor alpaca's: thermoregulatie, afrastering, ondergrond, sociale huisvesting

- Voer en voedermethodieken: verstrekking voer en water

- Bezettingsgraad: bezetting

- Specifieke behandelingsmethode( $\mathrm{n})$ : handling, algemene controle, voortplanting, scheren, tanden slijpen, nagels knippen, castreren

- Dodingsmethode( $\mathrm{n})$ : vangen, transport, verdoven/doden

- Biotechnologische handeling(en): kunstmatige inseminatie en embryotransplantatie

- Preventieve en curatieve diergeneeskundige zorg: ziekte-incidentie, hygiëne, behandelingen

- Wijze waarop met nakomelingen wordt omgegaan: spenen, eerste levensjaar

- Overige soortspecifieke eisen: $p m$

4. Doel waartoe de diersoort gehouden wordt - hier wordt ingegaan op het doel waartoe de alpaca wordt gehouden. De afweging tussen het doel waartoe het dier gehouden wordt enerzijds en de impact op de gezondheid en het welzijn van het dier anderzijds worden inzichtelijk gemaakt;

5. Ervaringen van elders met het houden van de betreffende diersoort - Ervaring die elders is opgedaan met het houden van alpaca's leert ons onder welke condities het houden kan plaatsvinden en in hoeverre vanuit gezondheids- en welzijnsoogpunt het houden van de diersoort voor productiedoeleinden op een aanvaardbare wijze kan plaatsvinden.

\section{Uit de informatie blijkt of de diersoort geschikt is als productiedier}

Het RDA-toetsingskader stelt dat hierbij met het volgende rekening moet worden gehouden:

Kan er worden voldaan aan geldende wet- en regelgeving?

In hoeverre worden welzijn en gezondheid geschaad? Wat is de ernst van de mogelijke welzijnsproblemen?

Zijn er voldoende mogelijkheden voor het goed managen van het bedrijfsmatig houden van de alpaca en om (risico op) diergezondheids- en/of dierenwelzijnsproblemen te minimaliseren?

In het rapport komen de genoemde onderdelen aan de orde. 


\subsection{Resultaten van de literatuurscan}

\subsubsection{Biologische karakteristieken van de diersoort}

De alpaca (Vicugna pacos) behoort tot de orde Artiodactyla (evenhoevigen), de suborde Tylopoda (eeltvoetigen) en de familie Camelidae (kameelachtigen) (Wilson and Reeder, 2005). Volgens de laatste inzichten behoort de alpaca niet tot het genus Lama maar tot het genus Vicugna en stamt af van de wilde vicuňa (Vicugana vicugna) (Kadwell et al. 2001). De alpaca vormt samen met de lama (Lama glama), de guanaco (Lama guanicoe) en de vicuňa (Vicugna vicugna) de Zuid-Amerikaanse kameelachtigen (SAC) (San Martin and Bryant 1989; Dufour et al. 2014). Alleen de lama en de alpaca zijn gedomesticeerd, 4000-6000 jaar geleden (Dufour et al. 2014). Er wordt ook wel gesproken van de 'New World Camelidae'. Kruisingen tussen de verschillende kameelachtigen zijn mogelijk (Gauly et al. 1997).

De alpaca is oorspronkelijk afkomstig uit Zuid-Amerika (Andesgebergte): Bolivia, Peru en Chili (Melo et al. 2011; San Martin and Bryant 1989). Op deze hoogvlakten (3.800 - 5.000 meter hoogte) heerst over het algemeen een landklimaat, waarbij zeer koude nachten afgewisseld worden met overdag een brandende zon (San Martin and Bryant 1989; Melo et al. 2011). De temperatuurrange is -10 tot $30^{\circ} \mathrm{C}$ (Gerken 2010). De hoeveelheid neerslag is gering en onregelmatig, 75\% van de regen valt tussen december en maart. De punavegetatie bestaat uit grassen, (korst)mossen en wat kruiden en struiken (Encyclopædia Britannica Online 2014; Ruthsatz 2012). Alpaca's worden oorspronkelijk in dit gebied door herders samen met andere SAC en schapen gehouden.

De Alpaca wordt van oorsprong gehouden voor de wol, daarnaast wordt het vlees ook gegeten. Binnen de Alpaca zijn twee fenotypen te onderscheiden: Suri en Huacaya (Brown 2000). De Huacaya komt het meeste voor en heeft licht krullende wol. De Suri heeft langere en steilere wol (San Martin and Bryant 1989).

Alpaca's hebben een schofthoogte van ongeveer één meter (76 - $104 \mathrm{~cm}$ ) en wegen tussen de 50 en $90 \mathrm{~kg}$ (D'Alterio 2006). De hengst (of macho) is forser dan de merrie (of hembra). In tegenstelling tot de herkauwers hebben de alpaca's geen klauwen, maar een eeltkussen met daaraan twee nagels. Hun lichaam is slank met een lange nek en ze hebben grote puntige oren, lange benen en een korte staart. Ze hebben geen horens of gewei. De anatomie van de achterste ledematen maakt dat de alpaca de poten onder het lichaam kan vouwen en op de buik kan rusten (Wheeler 1995).

Alpaca's zijn semi- of functionele herkauwers en onderscheiden zich van de andere herkauwers door een maag die uit drie in plaats van vier delen bestaat (Liu et al. 2009; San Martin and Bryant 1989). De maaginhoud bij een volwassen alpaca vertegenwoordigt ongeveer $17 \%$ van het lichaamsgewicht (San Martin and Bryant 1989). De alpaca heeft een gespeten bovenlip die zeer mobiel is, waardoor het dier selectief kan grazen. Alpaca's in Peru eten zowel de lange als de kortere grassoorten (San Martin and Bryant 1989). Alpaca's nemen het meeste voer op gedurende de dag (Robinson et al. 2005). Grazen doen de alpaca's met hun snijtanden, die een wigvormig snijvlak vormen waarmee de vegetatie wordt afgesneden tegen het tandvlees van de bovenkaak (San Martin and Bryant 1989). De snijtanden in de onderkaak groeien continu door. De samenstelling van het gebit is (onder- en bovenkaak): snijtanden 1/3, hoektanden 1/1, premolaren 1-2/1-2 en kiezen 3/3 x 2 (Fowler 1996). De snijtand in de bovenkaak is een hoektand en wordt, samen met de twee hoektanden in de onderkaak, gebruikt tijdens gevechten (George 1987). Het wisselen van de tanden voor het volwassen gebit vindt plaats op een leeftijd van twee tot vier jaar. Het gebit is compleet op een leeftijd van $3 \frac{1}{2}$ tot 5 jaar (Williams et al. 2010). Tijdens het kauwen bewegen de kaken horizontaal, waardoor de kiezen efficiënt het voer vermalen (San Martin and Bryant 1989). Deze zijwaartse beweging gaat verder dan bij paarden, waardoor er minder kans is op haken op de kiezen. Het mesten doen de dieren op één plek (McGregor and Brown 2010).

Alpaca's zijn territoriale dieren die in haremverband leven, bestaande uit één hengst en tot 20 merries met hun veulens (Duncanson 2012; Wheeler 1995). Alpaca's communiceren met elkaar op het gehoor, met het lichaam en de staartposities (Aba et al. 2010). De geluiden die ze maken zijn zeer divers in toonhoogte, frequentie en volume (Aba et al. 2010). 
Alpaca's zijn het hele jaar door vruchtbaar, maar waar merries en hengsten het hele jaar door in dezelfde groep lopen vinden de dekkingen in het grasgroeiseizoen plaats (Tibary and Vaughan 2006). Merries zijn vruchtbaar vanaf 5 tot 6 maanden, het kan voorkomen dat ze op 3 maanden al drachtig worden, afhankelijk van de voedingsstatus en gewicht. In de praktijk wordt met Alpaca-merries meestal vanaf eenjarige leeftijd gefokt, dan hebben ze 2/3 van hun volwassen gewicht bereikt (Vaughan and Tibary 2006). Vanaf een lichaamsgewicht van $33 \mathrm{~kg}$ heeft het gewicht geen invloed meer op de conceptie (Brown 2000).

Merries vertonen ovariële folliculaire groei in golven en zijn geïnduceerde ovulators Ze hebben geen vruchtbaarheidscyclus (en ook geen bronstseizoen), maar ovuleren nadat zij gedekt zijn. Ovulatie vindt plaats 24-30 uur na dekking. De mannelijke dieren kunnen seksuele interesse vertonen vanaf een jaar, maar zijn pas na de pubertijd (op 1 tot 3 jarige leeftijd) in staat te dekken, omdat dan de penis niet meer vastzit aan de voorhuid (Brown 2000; Tibary and Vaughan 2006). Alpacahengsten worden ingezet vanaf 3 jaar, ze zijn volwassen op 5 jaar (Brown 2000). De hengst achtervolgt de merrie en probeert de merrie op de grond te krijgen, de dekking vindt plaats in borstligging (Tibary and Vaughan 2006). De dekking duurt gemiddeld 20 minuten, maar dit kan variëren van een paar minuten tot meer dan een uur (Tibary and Vaughan 2006). De draagtijd is ongeveer $111 / 2$ maand (Vaughan 2011). De geboorte verloopt meestal vlot (Sumar 1996). Twee weken na de geboorte kan de merrie opnieuw worden gedekt (Sumar 1996). De merrie heeft vier melkklieren die alle eindigen in een tepel (George 1987). De jonge alpaca wordt een cria genoemd. Het geboortegewicht is 7 tot $8 \mathrm{~kg}$ (Brown 2000), dit verdubbelt in de eerste twee maanden (Chad et al. 2014). Een pasgeboren dier zal normaal binnen het uur staan, binnen 4 uur drinken en binnen 8 uur zal het eerste meconium worden uitgescheiden (Duncanson 2012). In de pubertijd wordt een alpaca ook wel tui genoemd (D'Alterio 2006).

In het wild worden alpaca's 12 jaar, in gevangenschap kunnen ze 20 jaar oud worden (Duncanson 2012).

De normale lichaamstemperatuur van een alpaca ligt tussen de 37,4 en $38,3^{\circ} \mathrm{C}$, de hartslag in rust tussen de 60 en 90 slagen (Duncanson 2012). Jongere dieren hebben een iets hogere lichaamstemperatuur dan volwassen dieren (Mattiello et al. 2011). Alpaca's kunnen goed omgaan met warmte, ze hebben een vrij brede thermo neutrale zone, hun lichaamstemperatuur houden ze tussen de 37 en $40^{\circ} \mathrm{C}$. Een verschil van $3^{\circ} \mathrm{C}$ in lichaamstemperatuur op een dag kan voorkomen (Mattiello et al. 2011; Duncanson 2012). Alpaca's hebben vrij kleine ovale rode bloedcellen (6,5 micron) en niet zoals alle andere zoogdieren ronde rode bloedcellen (10 micron). Ovale rode bloedcellen zijn in staat om na opname van grote hoeveelheden vocht meer op te zwellen dan ronde cellen. Daarnaast heeft een ovale cel een groter oppervlak waarmee meer zuurstof getransporteerd kan worden (Duncanson 2012; Fowler 1996). Voor de beoordeling van bloedmonsters van alpaca's moet gebruik worden gemaakt van specifieke referenties voor de soort, het normale aantal witte bloedcellen ligt bijvoorbeeld vrij hoog (Foster et al. 2009).

\subsubsection{Algemene informatie met betrekking tot het houden van de betreffende diersoort}

Alpaca's worden van oorsprong gehouden vooral voor hun vacht, het vlees wordt ook gegeten. Voor het houden van alpaca's is alpaca-specifieke kennis nodig bij de houder en dierenarts. Een alpaca heeft een heel ander gedrag dan een schaap: onderlinge communicatie, territoriaal gedrag, gebruik van latrines, afkoelen via onbewolde huid en zandbaden. Ook fysiologisch wijken alpaca's af van schapen of andere in Nederland gehouden productiedieren.

\subsubsection{Specifieke welzijnseisen met betrekking tot het houden van de betreffende} diersoort - relatie met welzijn en gezondheid

\section{Huisvesting}

Alpaca's kunnen jaar rond op de wei gehouden worden, maar hebben wel beschutting nodig (open frontstal is voldoende). Alpaca's kunnen goed omgaan met warmte, vanwege hun brede thermoneutrale zone (Duncanson 2012). Afkoeling vindt plaats door hijgen en via de huid van vooral de buik en tussen de poten (Gerken 2010). Alpaca's zoeken de schaduw, een vochtige zanderige plek 
of het water op om af te koelen (Fowler 1997). Bij temperaturen beneden $20^{\circ} \mathrm{C}$ en hoge windsnelheden kunnen vooral de jonge dieren problemen krijgen met hun thermoregulatie.

De alpaca's moeten de beschikking hebben over een droge sta- en ligplek (Jones and Boileau 2009;

Department of Agriculture Ohio 2011). Natte en modderige weides kunnen leiden tot ontstekingen aan de poten.

Alpaca's nemen graag een zandbad om de vacht te verzorgen (Gauly et al. 1997; Aba et al. 2010). De vacht van de alpaca bevat geen lanoline. Om waterafstoting en isolatie van de vacht te waarborgen is een geregeld stofbad nodig.

Bij de keuze voor de afrastering van de wei moet rekening worden gehouden met een drietal zaken:

1. door de vacht zijn alpaca's niet goed te houden binnen schrikdraad.

2. de alpaca heeft lange dunne poten en een lange nek waarmee ze klem kunnen komen te zitten in de afrastering.

3. de afrastering moet de vacht niet beschadigen, prikkeldraad is geen optie. De hoogte van de omheining voor alpaca's dient 1,20 - 1,50 meter te zijn. Indien er sprake is van meerdere groepen met territoriumgedrag is een hogere afscheiding nodig, of minimaal 6 meter afstand tussen de weides.

Voor voldoende afslijting van de nagels en de eeltlaag moet de ondergrond niet te zacht zijn. Een modderige ondergrond kan leiden tot ontstekingen aan de poten.

Alpaca's worden meestal gehouden in een groep bestaande uit hembra's met hun cria's (Gunsser 2009). De macho's kunnen in een aparte groep gehouden worden, maar dit kan tot onderlinge gevechten leiden (Aba et al. 2010; Gunsser 2009).

Pollard en Littlejohn (1995) concludeerden dat alpaca's acute stress ondervinden op het moment dat ze worden geïsoleerd van de kudde en in een klein hok worden geplaats. Dit uitte zich in een verhoogde hartslag, verplaatsingen door het hok, verticale of horizontale bewegingen van de kop tegen de afscheiding en het deurtje van het hok, besnuffelen van het hok, liggen in ventrale rusthouding en verminderde voeropname. De auteurs concludeerden dat de genoemde parameters nuttig kunnen zijn als indicatoren voor acute stress in vervolgonderzoek naar stressvolle houderijomstandigheden bij alpaca's (Pollard and Littlejohn 1995).

Over de houderij van alpaca's binnen in stallen hebben wij geen literatuur gevonden.

\section{Voer en voedermethodieken}

Alpaca's kunnen jaarrond geweid worden. Het winterrantsoen bestaat idealiter uit hooi, ongeveer $2 \mathrm{~kg}$ hooi per dier per dag met een maximum van $1.8 \%$ van het lichaamsgewicht (in $\mathrm{kg}$ droge stof) (Duncanson 2012). Alpaca's zijn zeer goed in staat om met ruwe celstof om te gaan, dit breken ze beter af dan schapen (Liesegang et al. 2005). Hierdoor hebben ze minder energie nodig per $\mathrm{kg}$ lichaamsgewicht dan een schaap (San Martin and Bryant 1989). Op voer met een hoog eiwitgehalte is dit verschil tussen schaap en alpaca verdwenen. Dit zou het gevolg kunnen zijn van de langere tijd dat het voer in de maag blijft bij een alpaca vergeleken met een schaap.

Afhankelijk van de kwaliteit hooi kan het nodig zijn een speciale alpacabrok bij te voeren (Duncanson 2012). In het rantsoen moet rekening worden gehouden met voldoende vitamine $D$, koper, ijzer, zink en selenium. Bij lacterende merries kan hypercalceamie voorkomen (Duncanson 2012).

Over de frequentie van voeren en eventuele voeronthouding voorafgaand aan het slachten is geen literatuur gevonden.

Alpaca's moeten net als andere landbouwhuisdieren altijd de beschikking hebben over schoon drinkwater. Hiervoor voldoen de methoden voor drinkwaterverstrekking zoals bekend uit de schapenhouderij.

\section{Bezettingsgraad}

Alpaca's zijn kuddedieren, hebben een efficiënte verwerking van gras en zullen mestplekken vermijden. Door hun efficiënte verwerking van het voer kunnen de dieren geweid worden met dezelfde bezettingsgraad als schapen (San Martin and Bryant 1989). In Zwitserland geeft de dierenbescherming een bezettingsgraad voor alpaca's aan voor een groep van maximaal 6 dieren per 
$250 \mathrm{~m}^{2}$, met voor elk extra dier $30 \mathrm{~m}^{2}$ erbij (Burri et al. 2005). In Noord-Amerika wordt een veel lagere bezettingsgraad van 5 tot 7 dieren per acre (ruim $4000 \mathrm{~m}^{2}$ ) aangehouden, met als

uitgangspunt dat dit voldoende beheersing van parasitaire infecties geeft en er niet wordt bijgevoerd (Jones and Boileau 2009). In Duitse literatuur wordt minimaal $1000 \mathrm{~m}^{2}$ voor de eerste twee dieren aangehouden en $100 \mathrm{~m}^{2}$ erbij voor elk extra dier (Gauly et al. 1997).

Opvallend is dat alpaca's een vaste plek voor het deponeren van hun mest en urine hebben (McGregor and Brown 2010). Op de plek van de latrines zal opeenstapeling van nutriënten plaats vinden. Het verwijderen van de mest is een manier om de wormbesmetting laag te houden. Alpaca's grazen bij hoge bezettingsgraad ook rondom de latrines, waardoor de infectiegraad met maagdarmwormen hoger is (McGregor and Brown 2010). Bij de bezettingsgraad kan daarnaast worden opgemerkt dat, naarmate er meer dieren gehouden worden er meer problemen kunnen optreden met wormbesmettingen dan bij kleinere eenheden. In Engeland waarschuwt de British Veterinary Camelid Society voor besmetting met rode lebmaagworm (Haemonchus contortus) in vochtige en milde zomers.

Alpaca's lijken het kortere gras te prefereren, waardoor het rotatiesysteem met een redelijk hoge bezettingsgraad ( $<0,5$ ton DM/ha) een efficiënte beweiding zal zijn (McGregor 2002). In het handboek voor SAC wordt een grashoogte van 4 tot $6 \mathrm{~cm}$ als optimaal genoemd (Duncanson 2012). De aan te bevelen bezettingsgraad in een stal is niet bekend.

\section{Specifieke behandelingsmethode(n)}

\section{Handling}

Handling van de alpaca's voor controle en behandelingen als vaccineren, bloedprikken, scheren, tanden slijpen of nagels knippen levert stress bij de dieren op. Een alpaca kan worden gevangen en vervolgens tegengehouden door het dier met een hand rond de hals beet te pakken, net onder het hoofd, en daarna de nek naar de eigen borst te trekken. De andere hand rust op het lichaam van de alpaca (D'Alterio 2006). Alpaca's zijn halstermak te maken, waardoor de handling makkelijker zal verlopen. Sommige dieren zullen luid vocaliseren, spugen of gaan liggen als ze worden vast gehouden. Regelmatig in handen hebben van de dieren zorgt voor de nodige gewenning (D'Alterio 2006). Hierin zijn er wel verschillen in gedrag tussen dieren (Duncanson 2012). Alpaca's die teveel contact hebben gehad met de mens op jonge leeftijd (bijvoorbeeld flescria's) kunnen de mens als soortgenoot gaan zien en dominant gedrag gaan vertonen (Duncanson 2012). Alpaca's zijn kuddedieren, gezamenlijk verplaatsen levert minder stress op dan dieren af te zonderen (Aba et al. 2010).

\section{Algemene controle}

Algemene gezondheidscontrole moet regelmatig plaatsvinden, waarbij wordt gelet op de kleur van de slijmvliezen, de body condition, aanwezigheid van ectoparasieten, de slijtage van de tanden en de nagels.

\section{Voortplanting}

De dekking kan plaats vinden door de merrie(s) en hengst los bij elkaar te laten gedurende een aantal dagen of weken, of door de hengst uit de hand te laten dekken. Bij het samenhouden van hengsten en merries moet er voldoende ruimte zijn om elkaar uit de weg te gaan. Hengsten kunnen nogal dwingend zijn naar de merries. Merries die drachtig zijn kunnen de hengst krachtig weren. Voortplantingstechnieken als kunstmatige inseminatie en embryotransplantatie staan bij de kameelachtigen in de kinderschoenen. Doordat de hengsten langdurig kleine beetjes ejaculeren is het sperma moeilijk te vangen (Tibary and Vaughan 2006; Brown 2000). Ook zijn er negatieve effecten op de spermakwaliteit en de hoeveelheid door de (nog) niet optimale kunstschede (Morton et al. 2010). Daarnaast zijn er nog, meest technische, problemen met de verdere behandeling van het (diepvries)sperma (Bravo et al. 2013). Embryotransplantatie is nog zelden toegepast (Rano et al. 2013).

\section{Scheren}

Voor het scheren van een alpaca worden de dieren meestal liggend gefixeerd, door de voorpoten en de achterpoten vast te binden (Duncanson 2012). Scheren kan het beste plaats vinden in de zomer, zodat de kans op hypothermie klein is (Mattiello et al. 2011). Door het scheren van een drachtige alpaca tijdens de eerste of de laatste 2 maanden van de dracht verhoogt de kans op afbreken van de 
dracht. Door de stress van het scheren wordt prostaglandine aangemaakt, dat luteolyse veroorzaakt (degeneratie van het corpus luteum, dat nodig is om de dracht in stand te houden) (Duncanson 2012).

\section{Tanden slijpen}

De snijtanden van alpaca's groeien door. Als deze niet juist afslijten moeten de tanden worden bijgeslepen. De vechttanden van de macho's worden soms ingekort. In de Code of Welfare voor lama's en alpaca's in Nieuw Zeeland wordt aangenomen dat dit geen negatieve impact heeft als het goed wordt uitgevoerd (www.fao.org/fileadmin/user_upload/animalwelfare/llama-and-alpaca-report.pdf).

\section{Nagels knippen}

De nagels van alpaca's slijten af op een harde ondergrond. Bij onvoldoende of scheve afslijting moeten de nagels worden bijgesneden.

\section{Castreren}

Hengsten die niet voor de fok worden ingezet maar wel voor de wol worden aangehouden, worden vaak gecastreerd tussen de 18 en 24 maanden (Burri et al. 2005).

\section{Dodingsmethode(n)}

\section{Transport}

Transport van alpaca's is goed mogelijk. Daarbij moeten de dieren niet worden aangebonden en er moet geen mogelijkheid zijn om de wagen uit te springen (Gunsser 2009).

\section{Verdoven en doden}

In de Europese wetgeving inzake de bescherming van dieren bij het slachten of doden wordt niet specifiek op kameelachtigen of alpaca's ingegaan (Euopese Unie 2009). In Engeland heeft het eerste slachthuis in 2011 een vergunning verkregen voor het slachten van alpaca's. De 'Humane Animal Slaughter Association' in Engeland geeft aan dat kameelachtigen met een penetrerend penschiettoestel moeten worden verdoofd (Humane slaughter association 2011).

Vaak worden gebruikelijke behandelingsmethoden en middelen van en voor runderen of kleine herkauwers geëxtrapoleerd naar de lama. Onderzoek naar vleeskwaliteit van alpaca's in Peru maakt melding van het slachten van alpaca's in rundveeslachterijen, waar ze verdoofd worden met behulp van een penetrerend schietmasker (Cristofanelli et al. 2004; Polidori et al. 2007).

In de 'Livestock care standards' van Ohio is aangegeven onder welke hoek de pen de kop van de alpaca moet binnendringen (Department of Agriculture Ohio 2011).

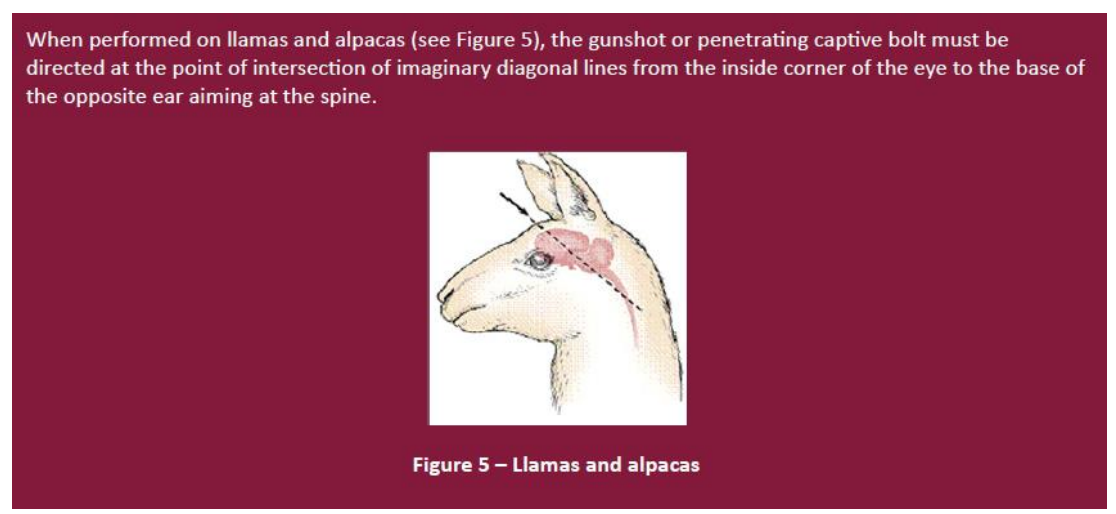

Een Brits recent onderzoek bevestigt dat een penetrerend schietmaker (penetrating captive bolt gun (CBG) stunning) bij alpaca's directe bewusteloosheid kan induceren. Zesennegentig alpaca's zijn geschoten met een penetrerend schietmasker, de Cash Special CBG met 0.22 paarse 2.5 gr (nominal propellant charge $190 \mathrm{mg}$ patronen) (Gibson et al, 2015). De alpaca's werden individueel in een hok geplaatst (individueel gefixeerd tussen 2 hekken waarbij hals/hoofd niet werden gefixeerd). Bij tien van de alpaca's (d.i. $9.8 \%$ ) was een $2^{\mathrm{e}}$ schot nodig om volledig verdoofd te raken. Incorrect geplaatste schoten waren in elk van de gevallen verantwoordelijk voor de onvolledige verdoving bij de tien alpaca's. Dit was vaker het geval bij schieten via de frontale positie ten opzichte van de top-of- 
the-head positie: reden waarom slechts 9 van de 96 alpaca's via de frontale positie zijn geschoten. Gibson et al. concludeerden uit het onderzoek dat alpaca's met een penetrerend schietmasker effectief kunnen worden verdoofd en dat de top-of-the-head positie (op de kruin) de, voor de directe complete bewusteloosheid noodzakelijke, schade aan de structuren van de thalamus en hersenstam maximaliseert en dus de beste positie is (te verkiezen boven de frontale positie). Zij concludeerden tevens dat een adequate fixatie van het hoofd- en nekgebied, waarbij het dier zo min mogelijk stress ondervindt, de accuraatheid van het schot zou kunnen verbeteren.

Het verdoven van de alpaca kan derhalve plaats vinden met een penetrerend penschiettoestel. Over elektrisch verdoven is geen informatie gevonden. Gezien de beharing van de kop van de alpaca kan elektrisch verdoven mogelijk niet goed worden uitgevoerd. Het slachthuispersoneel moet wel voldoende kennis hebben van het gedrag van alpaca's tijdens het huisvesten, verdoven en doden. Daarnaast moet de inrichting van het slachthuis dusdanig zijn dat de alpaca's zich niet kunnen verwonden aan hekwerken.

\section{Biotechnologische handeling(en)}

Kunstmatige inseminatie en embryotransplantatie zijn bij alpaca's relatief nieuwe technieken (Sumar 2013) (Bravo et al. 2013).

\section{Preventieve en curatieve diergeneeskundige zorg}

Artikel 2 van de Diergeneesmiddelenwet beschrijft dat diergeneesmiddelen alleen mogen worden toegepast indien ze voor de indicatie en de diersoort geregistreerd zijn. Voor alpaca's zijn geen middelen geregistreerd, zodat off-label use zal voorkomen (gebruik van geregistreerde geneesmiddelen voor een niet-geregistreerde indicatie).

In België worden schurft, maagdarmwormen en leverbot als meest voorkomende parasitaire infecties genoemd bij lama's (Xhonneux 2010). Bij alpaca's komen dezelfde maagdarmwormen en leverbot voor als bij de herkauwers die in Nederland wel al als productiedier worden gehouden: rund, schaap en geit (Fowler 1996). Ook komt coccidiosebesmetting voor (Rosadio et al. 2010; Fowler 1996). De kennis over de effectiviteit van antiparasitica tegen de verschillende parasieten bij alpaca's is beperkt (Thomas and Morgan 2013). Er zijn geen antiparasitica die zijn goedgekeurd voor alpaca's (Geurden and Van Hemelrijk 2005). In 'Merck veterinary manual' staan dan ook geen voor alpaca's goedgekeurde antiparasitica. Wel geeft de manual een lijst met middelen die in het algemeen als veilig worden beschouwd: ivermectine, pyrantel pamoate, en fenbendazole en clorsulon en albendazols tegen leverbotinfecties. Daar de werking van antiparasitica bij alpaca's niet volledig bekend is, wordt aangeraden via mestonderzoek na te gaan of de ingestelde behandeling afdoende is. Resistentie in alpaca's voor antiparasitica wordt in Canada en in de Verenigde Staten gemeld (Galvan et al. 2012; Gillespie et al. 2010).

Voor de wormbesmettingen bij alpaca's geldt hetzelfde als bij de herkauwer: de preventieve gezondheidszorg moet gericht zijn op het voorkomen van besmettingen, zoals mest verwijderen, en curatieve zorg na vaststellen van de besmettingen. Eitellingen in mest bij alpaca's met de bij schapen gehanteerde methode (McMaster telraam) kan leiden tot het missen van besmettingen van Capillaria en Trichuris soorten (D'Alterio 2006).

Ontwormen (maagdarmwormen en leverbot) en behandeling tegen coccidiose bij alpaca's lijken vooral van belang in het eerste levensjaar. Daarnaast wordt leverbot (fasciolosis) steeds vaker vastgesteld bij alpaca's in het Verenigd Koninkrijk (D'Alterio 2006). Alpaca's lijken gevoelig voor leverbot (Leguía 1991).

Huidziekten, met veel verschillende oorzaken, worden vaak gezien bij alpaca's (Scott et al. 2011). Het wordt veroorzaakt door ectoparasieten als mijt, bacteriële infecties en immunologische problemen (D'Alterio et al. 2005; Scott et al. 2011). Schurft door mijten (vooral Chorioptes spp, maar ook Sarcoptes spp en psoroptes $s p p$ ) veroorzaakt jeuk en kale plekken aan de achterpoten en staart en is lastig te bestrijden (Scott et al. 2011; Fowler 1996). 
In de literatuur zijn diverse virale infecties bij alpaca's gerapporteerd (McClenahan et al. 2013). In een Duitse studie zijn geen besmette dieren gevonden, waaruit men concludeerde dat het belangrijk is maatregelen te nemen om insleep van infecties te voorkomen: hygiëne, vermijdt direct en indirect contact tussen dieren van de verschillende bedrijven en test bij aankoop de dieren op virale infecties en stel een quarantaineperiode in (Locher et al. 2010). Alpaca's worden geënt tegen Clostridium perfringens enterotoxaemia, tetanus en leptospirosis; hierbij wordt de gebruiksaanwijzing voor schapen gebruikt (D'Alterio 2006).

Nederland is tuberculosevrij. Tuberculose (Mycobacterium bovis) kan bij geïmporteerde alpaca's voorkomen en is een meldingsplichtige besmettelijke dierziekte (Wernery and Kinne 2013). De screening op tuberculose bij alpaca's levert soms vals-negatieve resultaten op. Omdat er geen betere methode is, is de huidtest de aanbevolen diagnostiek bij import van dieren in de EU (Directive 92/65/EEC) (Broughan et al. 2013). Dromedarissen kunnen een reservoir voor Middle East Respiratory Syndrome (MERS) zijn. RIVM heeft internationaal onderzoek hiernaar geleid (Reusken et al. 2013). Daarin zijn bij dromedarissen uit Oman regelmatig antistoffen tegen het MERS-coronavirus aangetoond. Bij kameelachtigen uit o.a. Nederland, waaronder alpaca's, zijn geen antistoffen tegen het virus aangetoond. Duncanson (2012) geeft een overzicht van andere zoönosen die bij alpaca's kunnen voorkomen (o.a. cryptosporidiosis, Giardia).

De meest voorkomende niet-parasitaire problemen, gevonden in de periode 2000-2011 (6757 inzendingen) door het diagnostisch laboratorium in Engeland en Wales bij kameelachtigen, zijn voedingsziekten $(10.3 \%)$, sepsis $(5,9 \%)$, maagzweren $(4,5 \%)$, tumoren/neoplastische ziekten $(3,7 \%)$, tuberculose $(3,2 \%)$, clostridium $(2,5 \%)$, aangeboren afwijkingen $(2,3 \%)$, peritonitis $(2,2 \%)$ en de ziekte van Johne (1.1\%) (Twomey et al. 2014). Parasitaire ziektes kwamen meer voor: parasitaire gastro-enteritis $(18.2 \%)$, coccidiose $(10.6 \%)$, fascioliasis $(8,6 \%)$, ectoparasitaire aandoeningen $(4,9 \%)$ en cryptosporidiosis $(1,4 \%)$.

Alpaca's verschillen in fysiologie van schapen en andere landbouwhuisdieren. Onder andere zijn de rode bloedcellen ovaal en verschillen in grootte en vorm. Hierdoor geeft een telling met een standaard bloedtelmachine een niet-betrouwbaar beeld.

In Nederland heeft een klein aantal veterinairen zich (mede) gespecialiseerd in alpaca's. Vanwege de fysiologische bijzonderheden zoals het driemagenstelsel, de eeltpoten, afwijkende rode bloedcellen, het gebit en de voortplanting is specialistische kennis bij veterinaire bedrijfsbegeleiding van belang.

\section{Wijze waarop met nakomelingen wordt omgegaan}

Het geboortegewicht van alpacaveulens (cria's) is 7 á 8 kg (Bravo et al. 2009). De cria's worden in de praktijk gespeend rond de 6 maanden (Thomas and Morgan 2013). Spenen veroorzaakt stress bij de cria, die meetbaar is in een verhoogd cortisolgehalte gedurende 3 dagen (Bravo et al. 2001). Vooral de verzorging in het eerste levensjaar is belangrijk. Wormbesmettingen hebben in het eerste levensjaar de grootste impact (Thomas and Morgan 2013). Cria's zijn gevoelig voor diarree, de oorzaak is waarschijnlijk multifactorieel (voeding en pathogenen). In Amerikaans onderzoek bleek bij cria's de oorzaak van de diarree het coronavirus, Escherichia coli (E. coli), Cryptosporidium spp., Giardia spp. en coccidia (Whitehead and Anderson 2006).

Alpaca's zijn meestal vriendelijke dieren. Bij verkeerde opvoeding kunnen ze moeilijk te hanteren worden (Gunsser 2009). Dit komt vooral voor bij alpaca's die met de hand via flesvoeding worden groot gebracht. Deze alpaca's kunnen als volwassen dier agressief zijn naar mensen (Duncanson 2012). Cria's moeten dan ook niet van hun kudde worden gescheiden, ook niet als ze met de fles moeten worden grootgebracht.

\section{Overige soortspecifieke eisen}

De normale bloedwaarden die gehanteerd moeten worden bij alpaca's wijken af van die van andere productiedieren zoals een hoog aantal witte bloedcellen en door de afwijkende vorm en grootte van de rode bloedcellen. Hierdoor is het behandelen van en het uitvoeren van metingen aan het bloedmonster ook verschillend voor alpaca's en bijvoorbeeld schapen. 


\subsubsection{Doel waartoe de diersoort gehouden wordt}

Alpaca's worden (bedrijfsmatig) in het buitenland vooral gehouden voor de productie van de wol, waarbij de uitstootdieren voor de vleesconsumptie kunnen worden gebruikt.

De twee alpaca-fenotypen produceren een verschillende kwaliteit wol. Huacaya's produceren een dichte, zachte, krullerige, schaapachtige vezel; de Suri's produceren zijdeachtige, lange vezels, die enigszins op dreadlocks lijken. De wol van de Suri's brengt het meeste op.

Het vlees van de alpaca heeft een laag vet- en cholesterol percentage (Cristofanelli et al. 2005). Ook op andere vleeskwaliteitparameters scoort alpacavlees gunstig (Salva et al. 2009). Alpaca's zijn een belangrijke vleesbron voor bewoners van het Andes-gebergte. Daarnaast is er een toenemende vraag naar vlees van alpaca's en vooral lama's in rijkere landen vanwege het lage vet- en cholesterolgehalte.

Een alpaca levert per jaar 2 - 2,5 kg wol op (McGregor 2006; Wuliji 2011). Naast het gewicht is de kleur en de diameter van de vezels van invloed op de prijs (Alfonos et al. 2011; McGregor 2006). Op de particuliere markt wordt de wol nu voor rond de 20 euro per kilo verkocht. De markt voor goede kwaliteit wol lijkt op dit moment groeiende. De kosten van het scheren van een alpaca zijn hoger dan voor schapen, omdat er meer mensen nodig zijn voor het opdrijven en vasthouden van de dieren en het verpakken van de wol (Duncanson 2012). De aanschafprijs van een kwalitatief goede alpaca weegt momenteel economisch niet op tegen de opbrengst van de wol. Naast wolopbrengsten kunnen er inkomsten zijn uit verkoop van goede fokdieren, verkoop van dieren met een mindere kwaliteit wol/exterieur aan hobbydierhouders en eventueel verkoop van vlees van overtollige dieren (op dit moment is slachten in Nederland niet toegestaan).

\subsubsection{Ervaringen van elders met het houden van de betreffende diersoort.}

Kameelachtigen worden al duizenden jaren gehouden door de mens voor de wol en het vlees. In de afgelopen jaren is er een toename van het aantal alpaca's in Australië, Canada, Nieuw Zeeland en Amerika (Geurden and Van Hemelrijk 2005). In de Verenigde Staten werden in 2010150.000 alpaca's gehouden (Chad 2010). In Australië 40.000 (Duncanson 2012). Ook in Nederland en in de ons omringende landen neemt het aantal alpaca's toe (Verenigd Koninkrijk, Zwitserland en België). In het Verenigd Koninkrijk worden meer dan 35.000 alpaca's (als hobbydier of bedrijfsmatig) gehouden (Thomas and Morgan 2013). In Zwitserland waren 2.094 alpaca's geregistreerd in 2009 (Hilbe et al. 2012).

In Engeland hebben veterinairen en wetenschappers in 1994 'the British Veterinary Camelid Society' (www.camelidvets.org) opgericht die als doel heeft om als centrale bron van informatie en advies voor de klinische zorg voor alle kameelachtigen te zorgen in het Verenigd Koninkrijk.

\subsection{Ervaringsfeiten over gezondheid en welzijn}

In de literatuur zijn geen overzichten te vinden van de mate waarin gezondheidsproblemen bestaan van in Nederland gehouden alpaca's. 


\section{Resultaat van de bedrijfsaudit}

De bedrijfsaudit is uitgevoerd op 9 oktober 2014 door drie dierdeskundigen van Wageningen UR en een dierenarts met specialisatie dierentuindieren (o.a. kameelachtigen) en alpaca's. De audit bestond uit een aantal algemene vragen 'aan de keukentafel' met de eigenaren van het alpacabedrijf en daarna, in aanwezigheid van de alpacahouders, observatie van gedrag en gezondheid in de stal en weide en vaststellen van relevante houderijkenmerken. Het verslag van de bedrijfsaudit is een nietopenbare bijlage, alleen beschikbaar voor de opdrachtgever. Hieronder volgt een samenvatting van het resultaat van de bedrijfsaudit.

Het bedrijf heeft een nette en verzorgde uitstraling. De eigenaren staan ons bereidwillig te woord en verlenen alle medewerking aan de audit. Het bedrijf is in 2010 gestart met houden van enkele alpaca's. Nu in 2014 zijn er in wisselende aantallen tussen de 40 en 50 alpaca's aanwezig (inclusief hengsten en veulens). De eigenaren fokken met de alpaca's met als hoofddoel om de kwaliteit van de dieren (wol, exterieur) te verbeteren, ze gaan er regelmatig mee naar alpacashows. Een deel van de beste merries blijft op het bedrijf als fokmerrie; de beste hengsten worden als dekhengst aangehouden. De overige dieren zijn in de regel te koop. De eigenaren willen de mogelijkheid hebben om dieren die niet verder kunnen vanwege gebreken zoals kreupelheid, niet meer drachtig worden en andere oorzaken te laten slachten, evenals hobbykwaliteit dieren die na 2 jaar nog niet zijn verkocht. Het produceren van alpacavlees is geen hoofddoel en zal dit ook niet worden. Alpacavlees is wel heel smakelijk en gezond vanwege een laag vet- en cholesterolgehalte. Met enige regelmaat krijgt het bedrijf verwaarloosde dieren aangeboden, die om uiteenlopende redenen niet meer gewenst zijn door de huidige eigenaar. Ook alpacascheerders krijgen regelmatig dieren aangeboden van spijtoptanten. De eigenaren pleiten uit welzijnsoverwegingen voor de mogelijkheid om overtollige dieren te kunnen laten slachten. Tot de leeftijd van 5 jaar zijn dieren geschikt voor de slacht; oudere dieren kunnen nog wel verwerkt worden in gehakt en dergelijke. Men wil graag dat alpaca's mogen worden geslacht, met daarbij het liefst een minimale administratieve lastendruk voor alpaca-eigenaren (geen verplichting tot aanvraag UBN-nummer, mestregelgeving en dergelijke): zij pleiten voor een 'tussenoplossing' voor alpacahouders. Het bedrijf geeft aan op dit moment toestemming van de NVWA te hebben om overtollige alpaca's als 'harig wild' te laten slachten, onder voorwaarde dat dit bij een daartoe bevoegde slachter gebeurt. Het vlees wordt afgezet naar een specialiteitenrestaurant in Friesland.

Het bedrijf houdt de alpaca's in 5 productiegroepen:

- $\quad$ Een groep met merries, inclusief zuigende veulens.

- Een groep veulens (hengsten en merries) in de leeftijd van 6 maanden - 1 jaar.

- $\quad$ Een groep met hengstveulens vanaf de leeftijd van 1 jaar.

- $\quad$ Een groep met oudere hengsten, die nog niet zijn verkocht.

- $\quad$ Sinds kort ook dekkende hengsten samen in een groep (voorheen werden die apart in weitjes gehouden). De actief dekkende hengsten lopen niet bij de merries. De merries worden tussen 1 april en half september gedekt. De draagtijd is gemiddeld 11,5 maanden.

Veulens worden enkele weken na de geboorte gechipt en op een leeftijd van 5-7 maanden en minimaal $30 \mathrm{~kg}$ gewicht gespeend. Hengst- en merrieveulens komen dan in 1 groep bij elkaar. Na het spenen kunnen de veulens de moeders blijven zien via de afrastering: dat geeft rust. In april/mei worden de veulens geschoren en zo nodig worden gelijktijdig nagels en tanden behandeld (dan zijn ze 9-12 maanden oud) en worden hengsten en merries van elkaar gescheiden. De merries gaan terug naar de grote groep merries; de hengsten komen in een jaarlinggroep bij elkaar.

De 50 alpaca's hebben bij elkaar 2 hectare weiland ter beschikking, onderverdeeld in 11 verschillende percelen. Op het bedrijf zijn geen andere bedrijfsmatig gehouden dieren aanwezig. 


\section{Gedrag en comfort}

De alpaca's op het beoordeelde bedrijf hebben veel bewegingsvrijheid. De bezetting is laag, er zijn gemiddeld 50 dieren aanwezig op circa 2 hectare grond (gemiddeld $400 \mathrm{~m}^{2}$ per dier beschikbaar). De alpaca's beschikken continu en jaarrond over weidegang en over een schuilstal. Ieder perceel is uitgerust met een mogelijkheid tot zandbaden. De afrastering geeft minimale risico's op verwondingen. De omheining bestaat uit geplastificeerd gaas met een voldoende kleine maaswijdte; de hoogte van de omheining is $1.50 \mathrm{~m}$ met aan de bovenkant een metalen buis om 'hangen aan het gaas' te vermijden. De veulens worden gemiddeld op een leeftijd van 6 maanden -wat de gebruikelijke speenleeftijd is- gespeend. Minimale speenleeftijd is 5 maanden of $30 \mathrm{~kg}$ lichaamsgewicht. De gespeende veulens worden in groepen gehouden. Veulens worden iedere 10 dagen gewogen om hun ontwikkeling bij te houden. Indien flesvoeding noodzakelijk is, blijft het veulen zo mogelijk binnen de kudde. Veulens worden vanaf 5 maanden halster mak gemaakt. De houders gaan op rustige wijze met de dieren om; de dieren laten zich gemakkelijk verplaatsen of vangen. In de weide is geen vluchtgedrag of agressie (naar de mens of onderling) waargenomen. De kwaliteit van de weide was goed (weinig mest aanwezig, wordt twee keer per week met een biozuiger verwijderd); de vloeren in de (schuil-)stallen waren ingestrooid en schoon.

\section{Aandachtspunten}

Ten aanzien van gedrag en comfort zijn op het beoordeelde bedrijf geen aandachtspunten te vermelden.

\section{Gezondheid(szorg)}

Er is structureel aandacht voor beheersing van maag-darmwormen en ectoparasieten, waaronder schurft, er wordt routinematig tegen behandeld (dit is tevens een aandachtspunt; zie onder). Behandeling vindt plaats via injectie van elk dier afzonderlijk. Dit waarborgt een juiste dosering. Als de $-r$ - in de maand zit, krijgen de veulens iedere maand een vitaminespuit met $A D_{3}$. Er wordt geënt tegen 't bloed. In voorgaande jaren was er lage of geen uitval bij de veulens. Veulens worden iedere 10 dagen gewogen. De locomotie van de dieren is prima (slechts 1 dier licht kreupel). Er is geen noemenswaardige wol- of huidschade gezien. Er zijn geen zichtbare wonden gezien, ook niet bij de twee beoordeelde hengsten uit de hengstengroep. Indien nodig worden onvoldoende goed afgesleten snijtanden bijgeslepen (dit komt sporadisch voor). Bij één van de twaalf beoordeelde dieren werd de lengte van de snijtanden beoordeeld als 'matig', dat wil zeggen iets te lang, bij de overige dieren was de snijtandlengte prima. Hengsten van hobbykwaliteit worden niet routinematig gecastreerd, alleen als de koper hierom vraagt. De mest wordt twee keer per week met een biozuiger uit de weides verwijderd. Het stro in de stal is van prima kwaliteit, niet stoffig of schimmelig.

\section{Aandachtspunten}

Behandelingen tegen maag-darmwormen vinden routinematig plaats, zonder voorafgaand mestonderzoek om de noodzaak te staven en/of de resistentie tegen bepaalde middelen te toetsen. Injecteren kan tot kortdurend ongerief bij de dieren leiden (met name bij stroperige vloeistoffen). In 2014 twee abortussen als gevolg van een chlamydia-infectie (behandeling met antibiotica ingezet om die reden). De vechttanden van één van de hengsten waren ingekort, vanwege verwondingen bij andere dieren. Bij één van de tien merries is een voetzoolbeschadiging waargenomen die door de dierenarts als 'ernstig' werd geclassificeerd; bij één andere merrie werd een matige voetzoolbeschadiging gezien.

De alpaca's worden als wild geslacht bij een zelf slachtende slager. De zelf slachtende slager schetst het proces van verdoven en slachten als volgt: de alpaca wordt bij aankomst in het hokje gezet waar normaal ook de te slachten varkens staan. Daar worden ze verdoofd en direct getakeld en wordt de halssnede gezet (binnen $30 \mathrm{sec}$ na verdoving). Bij de eerste geleverde alpaca's heeft de slager de verdoving met de tang (elektrische stroomstoot) uitgevoerd, bij de andere alpaca's is een schietmasker gebruikt. De tang geeft volgens de slachter altijd de gewenste hoeveelheid stroom af, omdat het de weerstand meet. Bij een van de alpaca's kwam het halster tussen de tang, waardoor de tang niet goed werkte en de verdoving opnieuw moest worden gezet. Het gebruikte schietmasker is dezelfde als in het artikel van Gibson: Cash Special, waarbij de slachter de normale slagpen (0.22) en patronen (de groene) gebruikt die hij ook bij kalveren inzet. De positie van het masker is van boven af 
(dus kruinpositie) naar achter toe conform de aanbeveling van Gibson et al, 2015). Hierbij is de dot haar op de kop volgens de slachter geen belemmering. De controle op een correcte bedwelming is volgens de regels uitgevoerd (reflex oog, ademhaling, etc.). De toegepaste verdovingen werkten goed. Er is nooit een tweede schot nodig geweest.

Specifieke beoordeling van welzijnsindicatoren tijdens het transport en bij het verdoven en doden op het slachthuis maakte geen onderdeel uit van de bedrijfsaudit. Hierover kunnen we derhalve geen onderbouwde uitspraken doen.

\section{Voer en voeding (en drinkwater)}

De dieren hebben onbeperkt de beschikking over gras en/of een goede kwaliteit hooi, buiten de zomer aangevuld met bietenpulp en alpaca-biks, en ruim voldoende ruimte per dier om te vreten. In de grote stal en schuilstallen zijn voor ieder dier apart eetbakjes aanwezig met daarnaast gezamenlijke hooibakken en -ruiven. Er zijn voor de dieren ook voldoende drinkwatertonnen aanwezig; het verstrekte water is op het oog van goede kwaliteit (schone watertonnen); er wordt leidingwater verstrekt. De beoordeelde dieren zijn in het algemeen in goede of ruime conditie.

\section{Aandachtspunten}

Geen. 


\section{Is de alpaca geschikt als productiedier?}

Relevante vragen uit RDA-format, die beantwoord dienen te worden: Kan er worden voldaan aan geldende wet- en regelgeving? In hoeverre wordt welzijn en gezondheid geschaad? Wat is de ernst van mogelijke welzijnsproblemen? Zijn er voldoende mogelijkheden voor het goed managen van het houden van de alpaca om (risico op) diergezondheids- en/of dierenwelzijnsproblemen te minimaliseren?

\section{Wordt er voldaan aan geldende wet- en regelgeving?}

Alpaca's lijken regelmatig bij slachthuizen ter slacht te worden aangeboden, zowel door het beoordeelde bedrijf als door andere alpacahouders in Nederland. Aangezien de alpaca (nog) niet is aangewezen als productiedier is het slachten ervan strijdig met de geldende regelgeving. Het beoordeelde bedrijf geeft aan op dit moment toestemming te hebben van de NVWA om overtollige alpaca's als 'gekweekt wild' te laten slachten, onder voorwaarde dat dit gebeurt door een daartoe bevoegde slachter.

\section{In hoeverre wordt welzijn en gezondheid geschaad? Wat is de ernst van mogelijke welzijnsproblemen?}

In de WUR-rapporten 'Ongerief bij kalkoenen, eenden, schapen en geiten' en 'Ongerief bij rundvee, varkens, pluimvee, nertsen en paarden' is een expertview toegepast om ongerief (de negatieve kant van dierenwelzijn) bij de genoemde soorten productiedieren te beoordelen (Leenstra et al. 2009; Leenstra et al. 2011). Om de mate van het ongerief inzichtelijk te maken is ingeschat wat de ernst (E) is van het ongerief voor het individuele dier, hoe lang het dier het ongerief ondervindt (duur D) en welk deel van de populatie van de betreffende soort het ongerief ondervindt (de omvang O). De tabel met de daar gehanteerde criteria voor ernst, duur en omvang is weergegeven in bijlage 4 .

De literatuurscan in hoofdstuk 3 en de bedrijfsaudit geven een beeld van de vormen van ongerief die bij het bedrijfsmatig houden van alpaca's aan de orde kunnen zijn. Bepaalde oorzaken van ongerief kwamen ook naar voren in de ongeriefanalyse die voor andere bedrijfsmatig gehouden dieren (o.a. schapen) in bovengenoemd rapporten zijn uitgevoerd. Hieronder wordt een overzicht gegeven van mogelijke vormen van ongerief bij alpaca's in het algemeen en wordt aangegeven hoe wij vinden dat het geauditeerde bedrijf er op scoort (tabel 1 ). 
Tabel 1 Inschatting ongerief ${ }^{1}$ alpaca's op het beoordeelde bedrijf, mede afgeleid uit de ongeriefanalyses die zijn uitgevoerd bij andere diersoorten (Leenstra et al, 2009; Leenstra et al, 2011).

\begin{tabular}{|c|c|c|c|c|c|}
\hline \multirow[b]{2}{*}{ Oorzaak van ongerief } & \multirow[b]{2}{*}{$\begin{array}{l}\text { Leve } \\
\text { ns- } \\
\text { fase }\end{array}$} & \multirow[b]{2}{*}{ Ernst ongerief } & \multirow[b]{2}{*}{ Duur ongerief } & \multicolumn{2}{|c|}{$\begin{array}{l}\text { Score geauditeerd } \\
\text { alpacabedrijf }\end{array}$} \\
\hline & & & & $\begin{array}{l}\text { Deel koppel } \\
\text { met het } \\
\text { ongerief }\end{array}$ & $\begin{array}{l}\text { Totaal } \\
\text { score } \\
\text { bedrijf }\end{array}$ \\
\hline Ontbreken schuilplekken & alle & Mindere thermoregulatie (2) & Tijdelijk (1) & $(0)$ & $\mathbf{0}$ \\
\hline Spenen & $\begin{array}{l}\text { veule } \\
\text { ns }\end{array}$ & $\begin{array}{l}\text { Milde stress door plotseling } \\
\text { verbreken sociale band (1) }\end{array}$ & Tijdelijk (1) & (2) & 2 \\
\hline Kreupelen & alle & $\begin{array}{c}\text { Gewichtsverlies, pijn, stress } \\
(2)\end{array}$ & Tijdelijk (1) & (1) & 2 \\
\hline Parasitaire aandoeningen & alle & $\begin{array}{c}\text { Huidaandoeningen, jeuk, } \\
\text { gewichtsverlies, pijn, stress } \\
(2)\end{array}$ & Tijdelijk (1) & (0) & $\mathbf{0}$ \\
\hline $\begin{array}{l}\text { Onkunde beginnende } \\
\text { houder }\end{array}$ & alle & Ziekte, sterfte (1) & Tijdelijk (1) & $(0)$ & $\mathbf{0}$ \\
\hline $\begin{array}{l}\text { Behandelen (ontwormen, } \\
\text { vaccinatie e.d.) }\end{array}$ & alle & $\begin{array}{c}\text { Pijnreactie, napijn, milde } \\
\text { angst en stress, ontsteking, } \\
\text { spuitplek (1) }\end{array}$ & $\begin{array}{l}\text { Bij herhaling } \\
\text { kortdurend (1) }\end{array}$ & (2) & 2 \\
\hline Scheren & $\begin{array}{l}\text { volwa } \\
\text { ssen } \\
\text { dier }\end{array}$ & $\begin{array}{l}\text { Milde tot ernstige angst en } \\
\text { stress, verwonding (2) }\end{array}$ & Kortdurend (0) & (2) & $\mathbf{0}$ \\
\hline Te lange snijtanden & alle & $\begin{array}{l}\text { Belemmerde voedselopname } \\
\text { (2) }\end{array}$ & Tijdelijk (1) & (1) & 2 \\
\hline Tanden slijpen & alle & $\begin{array}{c}\text { Milde tot ernstige angst en } \\
\text { stress (2) }\end{array}$ & Kortdurend $(0)$ & Incidenteel (1) & $\mathbf{0}$ \\
\hline Vechttanden inkorten & $\begin{array}{l}\text { heng } \\
\text { st }\end{array}$ & $\begin{array}{l}\text { Milde tot ernstige angst en } \\
\text { stress (2) }\end{array}$ & Kortdurend (0) & Incidenteel (1) & $\mathbf{0}$ \\
\hline Te lange teennagels & alle & $\begin{array}{l}\text { Locomotieproblemen, pijn } \\
(1)\end{array}$ & Tijdelijk (1) & Incidenteel (1) & 1 \\
\hline Teennagels knippen & alle & Milde angst en stress (1) & Kortdurend (0) & $\begin{array}{l}\text { Bij herhaling } \\
\text { (1) }\end{array}$ & $\mathbf{0}$ \\
\hline Te natte weide/ stalvloer & alle & Voetzoolproblemen (2) & Tijdelijk (1) & $\begin{array}{l}\text { Incidenteel } \\
\text { (1) }\end{array}$ & 2 \\
\hline Voetzoollaesies infectieus & alle & $\begin{array}{l}\text { Locomotieproblemen, pijn } \\
\text { (2) }\end{array}$ & Tijdelijk (1) & Incidenteel (1) & 2 \\
\hline $\begin{array}{l}\text { Te hoge bezetting in } \\
\text { weide/stal }\end{array}$ & alle & $\begin{array}{l}\text { Onvoldoende } \\
\text { bewegingsruimte en } \\
\text { rustcomfort (1) }\end{array}$ & Structureel (2) & (0) & $\mathbf{0}$ \\
\hline $\begin{array}{l}\text { Sterfte pasgeboren veulens } \\
\text { door onvoldoende zorg }\end{array}$ & $\begin{array}{l}\text { veule } \\
\mathrm{n}\end{array}$ & $\begin{array}{l}\text { Uitdroging, onderkoeling, } \\
\text { ondervoeding ( } 2 \text { ) }\end{array}$ & (1) & (0) & $\mathbf{0}$ \\
\hline $\begin{array}{l}\text { Moederloze opfok buiten } \\
\text { kudde }\end{array}$ & $\begin{array}{l}\text { veule } \\
\mathrm{n}\end{array}$ & $\begin{array}{l}\text { Opgroeien zonder moeder, } \\
\text { meer gericht op mens ( } 1 \text { ) }\end{array}$ & Structureel (2) & $(0)$ & $\mathbf{0}$ \\
\hline $\begin{array}{l}\text { Onthouden dagelijkse } \\
\text { weidegang }\end{array}$ & alle & $\begin{array}{l}\text { Minder prikkels, beweging } \\
(1)\end{array}$ & Tijdelijk (1) & $(0)$ & $\mathbf{0}$ \\
\hline $\begin{array}{l}\text { Aanbrengen oormerk } \\
\text { (chip) }\end{array}$ & $\begin{array}{l}\text { veule } \\
\mathrm{n}\end{array}$ & $\begin{array}{l}\text { Pijnreactie, verwonding oor } \\
\text { (1) }\end{array}$ & Kortdurend $(0)$ & (2) & $\mathbf{0}$ \\
\hline Afwezigheid zandbad & alle & $\begin{array}{l}\text { Ontbreken huidverzorging, } \\
\text { gedragsbeperking ( } 2 \text { ) }\end{array}$ & Structureel (2) & (0) & $\mathbf{0}$ \\
\hline Ongeschikte afrastering & alle & $\begin{array}{l}\text { Verwondingen aan poten, } \\
\text { huid (1) }\end{array}$ & Tijdelijk (1) & $(0)$ & $\mathbf{0}$ \\
\hline $\begin{array}{l}\text { Gevechten tussen } \\
\text { hengsten }\end{array}$ & $\begin{array}{l}\text { Heng } \\
\text { st }\end{array}$ & Verwondingen, stress (2) & Kortdurend (0) & $(0)$ & $\mathbf{0}$ \\
\hline $\begin{array}{l}\text { Voedingstekorten } \\
\text { (vitamines) }\end{array}$ & Alle & Gezondheidsproblemen (2) & Structureel (2) & (0) & $\mathbf{0}$ \\
\hline Schimmelig/stoffig stro & Alle & Gezondheidsproblemen (2) & Structureel (2) & $(0)$ & $\mathbf{0}$ \\
\hline Slechte kwaliteit voeding & Alle & Gezondheidsproblemen (2) & Structureel (2) & (0) & $\mathbf{0}$ \\
\hline Castratie & $\begin{array}{l}\text { heng } \\
\text { st }\end{array}$ & Pijn, stress (2) & Tijdelijk (1) & (1) & 2 \\
\hline Slechte bodycondition & alle & Ondervoeding, te zwaar (1) & Tijdelijk (1) & (1) & 1 \\
\hline Ziekten divers & alle & Ongemak, pijn, stress (1-2) & Tijdelijk (1) & (1) & 1-2 \\
\hline Transport als koppel & alle & $\begin{array}{c}\text { Milde stress, angst voor het } \\
\text { onbekende (1) }\end{array}$ & Tijdelijk (1) & (1) & 1 \\
\hline Transport individueel & alle & $\begin{array}{c}\text { Stress door isolatie, angst } \\
(2)\end{array}$ & Tijdelijk (1) & (1) & 2 \\
\hline $\begin{array}{l}\text { Slechte mens-dier } \\
\text { interactie }\end{array}$ & alle & $\begin{array}{l}\text { Stress door confrontatie met } \\
\text { mens (1) }\end{array}$ & $\begin{array}{l}\text { incidenteel } \\
\text { (1) }\end{array}$ & $(0)$ & 0 \\
\hline $\begin{array}{l}\text { Individueel houden van } \\
\text { dieren }\end{array}$ & alle & $\begin{array}{c}\text { Stress door isolatie, angst } \\
(2)\end{array}$ & Structureel (2) & (0) & $\mathbf{0}$ \\
\hline
\end{tabular}

${ }^{1}$ In bijlage 3 staat de achterliggende methodiek met uitleg van de scores

2 Het is niet bekend voor welk deel van de populatie alpaca's in Nederland het betreffende ongerief van toepassing zal zijn. Hier is op dit moment door een volledig gebrek aan informatie ook geen inschatting van te maken. Daarom is hier nagegaan hoe zwaar het ongerief telt indien het voor de hele populatie van toepassing zou zijn.

\footnotetext{
${ }^{1}$ In Bijlage 3 staat de achterliggende methodiek met uitleg van de scores
} 


\section{Conclusie}

\section{Algemeen}

Potentiele welzijnsknelpunten bij het (extensief) houden van alpaca's hangen onder andere samen met te natte weiden en het ontbreken van droge sta- en ligplekken in stallen, waardoor o.a. een risico op voetzoolaandoeningen ontstaat; de afwezigheid van de mogelijkheid om te zandbaden; onvoldoende kwaliteit van voeding en stro; en een te hoge bezetting. Daarnaast stellen alpaca's specifieke eisen aan de verzorging, zoals een goede beheersing van parasitaire aandoeningen, het zonodig bijslijpen van snijtanden en het knippen van teennagels; scheren, verzorging van moederloze veulens binnen de kudde; en een goede handling van dieren. Impulsaankopen zijn om die reden ongewenst: een goede verdieping vooraf in de specifieke eisen die het ras stelt aan houderij en verzorging alsmede betrokkenheid van een dierenarts (eventueel naast de reguliere dierenarts voor operationele handelingen) die is gespecialiseerd in kameelachtigen zijn randvoorwaarden om welzijnsproblemen te voorkomen.

\section{Geauditeerd bedrijf}

Op grond van de bedrijfsaudit en tabel 1 concluderen wij dat er geen ernstige welzijnsaantastingen op het geauditeerde alpacabedrijf voorkomen. Het voorkomen van voetzoollaesies vormt wel een aandachtspunt (geringe welzijnsaantasting: bij 2 van de 12 beoordeelde dieren werd een voetzoollaesie vastgesteld (een matige en een ernstige). De oorzaak van de voetzoollaesies lijken volgens de dierenarts niet infectieus te zijn (er wordt een relatie met natte ondergrond vermoed). Weides en stalvloeren zijn op het moment van de audit gekwalificeerd als 'droog'. De chlamydiauitbraak dit jaar vormt een geringe welzijnsaantasting. Hetzelfde geldt voor het relatief grote aantal standaardbehandelingen dat het bedrijf per injectie uitvoert (routinematig ontwormen 2x per jaar; vaccinaties e.a.). Niet-vermijdbare handelingen zoals het aanbrengen van een identificatiemiddel (chip) en in incidentele gevallen castratie van hengsten als een koper-hobbydierhouder daarom vraagt, vormen eveneens een geringe welzijnsaantasting. Beoordeling van het proces van transport naar verdoven en doden op het slachthuis maakte geen onderdeel uit van de bedrijfsaudit. Hierover kunnen wij derhalve geen onderbouwde uitspraken doen. De alpaca's werden door een zelf slachtende slager via een penetrerend schietmasker ( 0.22 slagpen met groene patronen conform die voor kalveren) verdoofd, inclusief controle op een correcte bedwelming, en geslacht. De positie van het schietmasker was conform de aanbeveling van Gibson et al (2015).

Daarnaast zijn er op het geauditeerde bedrijf een aantal duidelijke positieve punten voor het welzijn, zoals de rustige wijze waarop met de dieren wordt omgegaan (mens-dierinteractie), de ruime beschikbare oppervlakte per dier aan weide, de aanwezigheid van zandbakken in alle weiden, de schuilmogelijkheden voor alle dieren, de huisvesting in groepen, ook van de actief dekkende hengsten, en positieve punten op het gebied van o.a. voeding.

\section{Zijn er voldoende mogelijkheden voor het goed managen van het houden van de alpaca om (risico op) diergezondheids- en/of dierenwelzijnsproblemen te minimaliseren?}

Op basis van de literatuurscan en de uitgevoerde bedrijfsaudit zijn we van mening dat er in principe voldoende mogelijkheden zijn voor het goed managen van het houden van de alpaca als productiedier, mits aan een aantal voorwaarden wordt voldaan om het risico op welzijns- en gezondheidsproblemen te minimaliseren:

Voor het houden van alpaca's is alpaca-specifieke kennis nodig bij houder en dierenarts. De dieren dienen adequaat te worden verzorgd en rustig te worden gehanteerd bij controle, behandelingen, transport (en tijdens verdoven/doden bij aankomst op de slachterij) om stress te beperken. Speciaal van belang zijn een rustige handling bij verplaatsen van groepen dieren en vangen/vasthouden/behandelen van individuele dieren; knippen van teennagels indien deze onvoldoende afslijten; bijslijpen van te lange snijtanden; regelmatige controle op voetzoollaesies; een goede beheersing van endo- en ectoparasieten; goede kennis van bij alpaca's voorkomende ziekten; en de opfok van moederloze veulens binnen de koppel. Bij bijzondere afwijkingen dient een in alpaca's en/of andere kameelachtigen gespecialiseerde dierenarts te worden geraadpleegd. 
$>$ Houd de bezettingsgraad laag, zorg dat de dieren over voldoende oppervlakte weide en stal beschikken. De adviezen hierover lopen uiteen en zijn afhankelijk van wel of niet bijvoeren van de dieren en de wijze van beheersing van parasitaire infecties (van circa $40 \mathrm{~m}^{2}$ per dier (Zwitserse Dierenbescherming; met bijvoedering) via circa $120 \mathrm{~m}^{2}$ per dier (Duitse literatuur) tot $570 \mathrm{~m}^{2}$ per dier (Noord-Amerika; geen bijvoedering)). Alpaca's zijn uitgesproken kuddedieren en dienen bij voorkeur niet individueel te worden gehouden in weide/stal (minimaal 2 dieren bij elkaar).

> Voorkom via managementmaatregelen het ontstaan van voetzoollaesies bij de dieren. Zorg dat alle dieren op ieder moment de beschikking hebben over een overdekte schuilmogelijkheid, waarin ze droog kunnen staan en liggen. Zorg dat dieren niet op natte en modderige weides hoeven te staan.

> Zorg voor de aanwezigheid van een 'zandbak', een plek waarin de dieren kunnen zandbaden om de noodzakelijke vachtverzorging uit te voeren.

> Vervoer dieren bij transport niet-aangebonden en bij voorkeur met meerdere dieren tegelijk.

Uit recente literatuur (Gibson et al., 2015) komt naar voren dat het verdoven van alpaca's voorafgaand aan doden/slachten effectief kan plaatsvinden met een penetrerend schietmasker (paarse 2,5 grams slagpen, kruitlading $190 \mathrm{mg}$ ). De top-of-the-head positie van het schietmasker (op de kruin) is daarbij de beste positie, en heeft de voorkeur boven de frontale positie.

\section{Onderscheiden marktwaarde en dierenwelzijn}

Alpaca's worden (bedrijfsmatig) in het buitenland vooral gehouden voor de productie van de wol, waarbij de uitstootdieren voor de vleesconsumptie kunnen worden gebruikt. De twee alpaca-fenotypen produceren een verschillende kwaliteit wol. Huacaya's produceren een dichte, zachte, krullerige, schaapachtige vezel; de Suri's produceren zijde-achtige, lange vezels, die enigszins op dreadlocks lijken. De wol van de Suri's brengt het meeste op. Naast wolopbrengsten kunnen er inkomsten zijn uit verkoop van goede fokdieren, verkoop van dieren met een mindere kwaliteit wol/exterieur aan hobbydierhouders en eventueel verkoop van vlees van overtollige dieren (op dit moment is slachten in Nederland niet toegestaan). Het vlees van de alpaca heeft een laag vet- en cholesterol percentage. Ook op andere vleeskwaliteitsparameters scoort alpacavlees gunstig. Alpaca's zijn een belangrijke vleesbron voor bewoners van het Andes-gebergte. Daarnaast is er een toenemende vraag naar vlees van alpaca's en vooral lama's in rijkere landen vanwege het lage vet- en cholesterolgehalte. Tegenover het doel van de productie op het beoordeelde bedrijf (wol, verkoop van fok- en gebruiksdieren, en de mogelijkheid om niet-plaatsbare overtollige dieren te laten slachten voor het vlees) staan, naast diverse positieve aspecten voor dierenwelzijn, enkele als gering gescoorde welzijnsaantastingen. In hoeverre het productiedoel qua nut en noodzaak opweegt tegen deze geringe welzijnsaantastingen vraagt om een ethisch/politieke afweging en valt buiten het bestek van de adviesopdracht. 


\section{$5 \quad$ Advies}

\section{Geschiktheid als productiedier}

Op basis van de literatuurscan en de uitgevoerde bedrijfsaudit zijn wij van mening dat de alpaca op basis van het gehanteerde toetsingskader in principe geschikt is om als productiedier te worden gehouden, mits aan een aantal voorwaarden wordt voldaan om het risico op gezondheids- en welzijnsproblemen te minimaliseren (zie hoofdstuk 4).

Op het moment van de bedrijfsaudit zijn er op het alpaca-bedrijf geen belangrijke welzijns- of gezondheidsproblemen waargenomen. Het geauditeerde bedrijf voldoet op dit moment (ruimschoots) aan de genoemde voorwaarden voor minimaliseren van het risico op gezondheids- en welzijnsproblemen.

\section{Bedwelmen en doden}

Specifieke beoordeling van welzijnsindicatoren tijdens transport en bij het verdoven/doden op het slachthuis maakte geen onderdeel uit van de bedrijfsaudit. Hierover kunnen wij derhalve geen onderbouwde uitspraken doen. In een recent Brits onderzoek naar bedwelmen van alpaca's met een penetrerend schietmasker wordt een aanbeveling gedaan om in de procedure op te nemen wat de positie van het masker zou moeten zijn. Tevens concluderen zij dat een adequate fixatie van het hoofd-/nekgebied, waarbij het dier zo min mogelijk stress ondervindt, de accuraatheid van het schot verder zou kunnen verbeteren. Dit onderzoek (Gibson et al. 2015) zou van waarde kunnen zijn om de huidige Nederlandse manier van verdoven van alpaca's aan te toetsen en waar nodig te verbeteren.

NB. Onze beoordeling van de geschiktheid van de alpaca als productiedier is uitgevoerd in het licht van de bedrijfsomstandigheden waaronder de alpaca's op het geauditeerde bedrijf op extensieve wijze worden gehouden, met continu en jaarrond weidegang. 


\section{Literatuur}

Aba, M. A., C. Bianchi, and V. Cavilla. 2010. "South American camelids." In Behavior of exotic pets, edited by V.V. Tynes, 157-167. John Wiley \& Sons.

Alfonos, L., J. BBuritica, R. Quispe, and I. Quicano. 2011. "Derivation of economic values for fibre diameter fleece weight in alpacas." In Fibre production in South Amercan camelids and other fibre animals, edited by M.A.; Cutiérres Pérez-Cabal, J.P.; Cervantes, I.; Alcalde, M.J., 145-150. Wageningen Academic Publishers.

Bravo, P. W., V. Alarcon, L. Baca, Y. Cuba, C. Ordonez, J. Salinas, and F. Tito. 2013. Semen preservation and artificial insemination in domesticated South American camelids. Animal Reproduction Science 136 (3): 157-163. http://dx.doi.org/10.1016/j.anireprosci.2012.10.005.

Bravo, P. W., J. Garnica, and E. Aviles. 2001. Cortisol concentrations in the perinatal and weaning periods of alpacas. Animal Reproduction Science 67 (1-2): 125-129. http://dx.doi.org/http://dx.doi.org/10.1016/S0378-4320(01)00112-9.

Bravo, P. W., J. Garnica, and G. Puma. 2009. Cria alpaca body weight and perinatal survival in relation to age of the dam. Animal Reproduction Science 111 (2-4): 214-219. http://dx.doi.org/http://dx.doi.org/10.1016/j.anireprosci.2008.03.001.

Broughan, J. M., T. R. Crawshaw, S. H. Downs, J. Brewer, and R. S. Clifton-Hadley. 2013. Mycobacterium bovis infections in domesticated non-bovine mammalian species. Part 2: A review of diagnostic methods. The Veterinary Journal 198 (2): 346-351. http://dx.doi.org/http://dx.doi.org/10.1016/j.tvjl.2013.09.007.

Brown, B. W. 2000. A review on reproduction in South American camelids. Animal Reproduction Science 58 (3-4): 169-195. http://dx.doi.org/http://dx.doi.org/10.1016/S0378-4320(99)00081-0.

Burri, I. H., J. Martig, H. Sager, A. Liesegang, and M. Meylan. 2005. South American camelids in Switzerland. I. Population, management and health problems. Schweizer Archiv Fur Tierheilkunde 147 (8): $325-$ 334.

Chad, E. K. 2010. Nutrient composition of alpaca (Vicugna Pacos) milk, Animal Science, California State University, Fresno.

Chad, E. K., E. J. DePeters, B. Puschner, S. J. Taylor, and J. Robison. 2014. Preliminary investigation of the composition of alpaca (Vicugna pacos) milk in California. Small Ruminant Research 117 (2-3): 165168. http://dx.doi.org/10.1016/j.smallrumres.2013.12.032.

Cristofanelli, S., M. Antonini, D. Torres, P. Polidori, and C. Renieri. 2004. Meat and carcass quality from Peruvian llama (Lama glama) and alpaca (Lama pacos). Meat Science 66 (3): 589-593. http://dx.doi.org/http://dx.doi.org/10.1016/S0309-1740(03)00174-8.

2005. Carcass characteristics of peruvian llama (Lama glama) and alpaca (Lama pacos) reared in the Andean highlands. Small Ruminant Research 58 (3): 219-222. http://dx.doi.org/10.1016/j.smallrumres.2004.10.004.

D'Alterio, G. L. 2006. Introduction to the alpaca and its veterinary care in the UK. In Practice 28 (7): 404411.

D'Alterio, G. L., A. P. Jackson, T. G. Knowles, and A. P. Foster. 2005. Comparative study of the efficacy of eprinomectin versus ivermectin, and field efficacy of eprinomectin only, for the treatment of chorioptic mange in alpacas. Veterinary Parasitology 130 (3-4): 267-275. http://dx.doi.org/http://dx.doi.org/10.1016/j.vetpar.2005.03.036.

Department of Agriculture Ohio. 2011. Ohio livestock care standards: ovine, caprine, camelid.

Dufour, E., N. Goepfert, B. G. Leon, C. Chauchat, R. F. Jordan, and S. V. Sanchez. 2014. Pastoralism in Northern Peru during Pre-Hispanic Times: Insights from the Mochica Period (100-800 AD) Based on Stable Isotopic Analysis of Domestic Camelids. Plos One 9 (1). http://dx.doi.org/10.1371/journal. pone.0087559.

Duncanson, G. R. 2012. Veterinary treatment of llamas and alpacas. Wallingford: CABI.

Encyclopædia Britannica Online, s. v. 2014. Altiplano In Encyclopaedia Britannica.

Euopese Unie. 2009. VERORDENING (EG) Nr. 1099/2009 VAN DE RAAD van 24 september 2009 inzake de bescherming van dieren bij het doden.

Foster, A., C. Bidewell, J. Barnett, and R. Sayers. 2009. Haematology and biochemistry in alpacas and llamas. In Practice 31 (6): 276-281.

Fowler, M. E. 1996. Husbandry and diseases of camelids. Revue Scientifique Et Technique De $L$ Office International Des Epizooties 15 (1): 155-169. 
Fowler, M. E. 1997. Medical management of South American camelids in North America. Journal of Camel Practice and Research 4 (2): 123-129.

Galvan, N., J. R. Middleton, D. W. Nagy, L. G. Schultz, and J. W. Schaeffer. 2012. Anthelmintic resistance in a herd of alpacas (Vicugna pacos). Canadian Veterinary Journal-Revue Veterinaire Canadienne 53 (12): 1310-1313.

Gauly, M., W. Egen, and M. Trah. 1997. The husbandry of South American camelids maintained under middle European conditions. Tierarztliche Umschau 52 (6): 343-\&.

George, G. 1987. Llamas and alpacas - a summary of current information. Surveillance 14 (2): 6-7.

Gerken, M. 2010. Relationships between integumental characteristics and thermoregulation in South American camelids. animal 4 (09): 1451-1459. http://dx.doi.org/doi:10.1017/S1751731109991443.

Geurden, T., and K. Van Hemelrijk. 2005. Ivermectin treatment against gastrointestinal nematodes in New World camelids in Belgium. Small Ruminant Research 58 (1): 71-73. http://dx.doi.org/http://dx.doi.org/10.1016/j.smallrumres.2004.09.002.

Gibson, T. J., C. Whitehead, R. Taylor, O. Sykes, N. M. Chancellor, and G. Limon. 2015. Pathophysiology of penetrating captive bolt stunning in Alpacas (Vicugna pacos). Meat Science 100 (0): 227-231. http://dx.doi.org/http://dx.doi.org/10.1016/j.meatsci.2014.10.022.

Gillespie, R.-A. M., L. H. Williamson, T. H. Terrill, and R. M. Kaplan. 2010. Efficacy of anthelmintics on South American camelid (Ilama and alpaca) farms in Georgia. Veterinary Parasitology 172 (1-2): 168-171. http://dx.doi.org/http://dx.doi.org/10.1016/j.vetpar.2010.04.009.

Gunsser, I. 2009. Problems in keeping and in transporting of llamas and alpacas. Deutsche Tierarztliche Wochenschrift 116 (3): 121-+. http://dx.doi.org/10.2376/0341-6593-116-121.

Hilbe, M., C. Kaufmann, K. Zlinszky, P. Zanolari, and F. Ehrensperger. 2012. New World camelids and Bovine Virus Diarrhea Virus (BVDV) infection in Switzerland. Schweizer Archiv Fur Tierheilkunde 154 (4): 155-158. http://dx.doi.org/10.1024/0036-7281/a000320.

Humane slaughter association. 2011. Slaughter and killing of minority farmed species. 25.

Jones, M., and M. Boileau. 2009. Camelid Herd Health. Veterinary Clinics of North America: Food Animal Practice 25 (2): 239-263. http://dx.doi.org/http://dx.doi.org/10.1016/j.cvfa.2009.02.006.

Kadwell, M., M. Fernandez, H. F. Stanley, R. Baldi, J. C. Wheeler, R. Rosadio, and M. W. Bruford. 2001. Genetic analysis reveals the wild ancestors of the llama and the alpaca. 268 (1485): 2575-2584.

Leenstra, F., F. Neijenhuis, B. Bosma, M. Ruis, G. Smolders, and K. Visser. 2011. Ongerief bij rundvee, varkens, pluimvee, nertsen en paarden: eerste herhaling = Discomfort among cattle, pigs, poultry, mink and horses: first repetition. Rapport / Wageningen UR Livestock Research;456. Lelystad: Wageningen UR Livestock Research.

Leenstra, F. R., J. M. Rommers, P. Koene, M. A. W. Ruis, H. J. Schuiling, and J. C. Verkaik. 2009. Ongerief bij konijnen, kalkoenen, eenden, schapen en geiten; inventarisatie en prioritering = Discomfort among rabbit, turkey, duck, sheep and goat; inventory and priorization. Rapport / Wageningen UR, Animal Sciences Group;160. Lelystad: Wageningen UR, Animal Sciences Group.

Leguía, G. 1991. Enfermedades parasitarias. Edited by Fernández-Baca S. 325-362 vols. Avances y perspectivas del conocimiento de los camélidos sudamericanos. Santiago de Chile: FAO.

Liesegang, A., I. H. Burri, and M. Meylan. 2005. South American camelids in Switzerland. III. Digestibilities of different feedstuff. Schweizer Archiv Fur Tierheilkunde 147 (8): 345-349. http://dx.doi.org/10.1024/0036-7281.147.8.345.

Liu, Q., C. S. Dong, H. Q. Li, W. Z. Yang, J. B. Jiang, W. J. Gao, C. X. Pei, and Z. Q. Liang. 2009. Forestomach fermentation characteristics and diet digestibility in alpacas (Lama pacos) and sheep (Ovis aries) fed two forage diets. Animal Feed Science and Technology 154 (3-4): 151-159. http://dx.doi.org/http://dx.doi.org/10.1016/j.anifeedsci.2009.08.012.

Locher, L., H. Nieper, J. Volkery, M. Furll, and T. Wittek. 2010. Testing for BTV, BVDV and BHV-1 in blood samples of new world camelids kept in Middle Germany. Berliner Und Munchener Tierarztliche Wochenschrift 123 (11-12): 482-487. http://dx.doi.org/10.2376/0005-9366-123-482.

Mattiello, S., E. Formis, and S. Barbieri. 2011. Thermoregulation of alpacas bred in Italy. International Journal of Biometeorology 55 (2): 213-218. http://dx.doi.org/10.1007/s00484-010-0326-0.

McClenahan, S. D., G. Scherba, L. Borst, R. L. Fredrickson, P. R. Krause, and C. Uhlenhaut. 2013. Discovery of a Bovine Enterovirus in Alpaca. PLOS one august 12, 2013. http://dx.doi.org/DOI: 10.1371/journal. pone.0068777.

McGregor, B. A. 2002. Comparative productivity and grazing behaviour of Huacaya alpacas and Peppin Merino sheep grazed on annual pastures. Small Ruminant Research 44 (3): 219-232. http://dx.doi.org/http://dx.doi.org/10.1016/S0921-4488(02)00050-0.

2006. Production, attributes and relative value of alpaca fleeces in southern Australia and implications for industry development. Small Ruminant Research 61 (2-3): 93-111. http://dx.doi.org/http://dx.doi.org/10.1016/j.smallrumres.2005.07.001. 
McGregor, B. A., and A. J. Brown. 2010. Soil nutrient accumulation in alpaca latrine sites. Small Ruminant Research 94 (1-3): 17-24. http://dx.doi.org/http://dx.doi.org/10.1016/j.smallrumres.2010.06.004.

Melo, C., A. Manunza, M. Melo, L. Olivera, and M. Amills. 2011. "Analysis of the mitochrondial diversity of alpacas in eight farming areas of the south of Peru." In Fibre production in South Amercan camelids and other fibre animals, edited by M.A.; Cutiérres Pérez-Cabal, J.P.; Cervantes, I.; Alcalde, M.J., 87-91. Wageningen Academic Publishers.

Morton, K. M., P. C. Thomson, K. Bailey, G. Evans, and W. M. C. Maxwell. 2010. Quality Parameters for Alpaca (Vicugna pacos) Semen are Affected by Semen Collection Procedure. Reproduction in Domestic Animals 45 (4): 637-643. http://dx.doi.org/10.1111/j.1439-0531.2008.01321.x.

Polidori, P., M. Antonini, D. Torres, D. Beghelli, and C. Renieri. 2007. Tenderness evaluation and mineral levels of llama (Lama glama) and alpaca (Lama pacos) meat. Meat Science 77 (4): 599-601. http://dx.doi.org/http://dx.doi.org/10.1016/j.meatsci.2007.05.011.

Pollard, J. C., and R. P. Littlejohn. 1995. Effects of social isolation and restraint on heart rate and behaviour of alpacas. Applied Animal Behaviour Science 45 (1-2): 165-174. http://dx.doi.org/http://dx.doi.org/10.1016/0168-1591(95)00588-J.

Rano, M. H., M. E. Silva, W. Huanca, T. Huanca, and G. P. Adams. 2013. Induction of superovulation in South American camelids. Animal Reproduction Science 136 (3): 164-169. http://dx.doi.org/10.1016/j.anireprosci.2012.10.006.

Reusken, C. B. E. M., B. L. Haagmans, M. A. Müller, C. Gutierrez, G.-J. Godeke, B. Meyer, D. Muth, et al. 2013. Middle East respiratory syndrome coronavirus neutralising serum antibodies in dromedary camels: a comparative serological study. The Lancet Infectious Diseases 13 (10): 859-866. http://dx.doi.org/http://dx.doi.org/10.1016/S1473-3099(13)70164-6.

Robinson, T. F., B. L. Roeder, G. B. Schaalje, J. D. Hammer, S. Burton, and M. Christensen. 2005. Nitrogen balance and blood metabolites of alpaca (Lama pacos) fed three forages of different protein content. Small Ruminant Research 58 (2): 123-133. http://dx.doi.org/http://dx.doi.org/10.1016/j.smallrumres.2004.09.005.

Rosadio, R., P. Londoñe, D. Pérez, H. Castillo, A. Véliz, L. Llanco, K. Yaya, and L. Maturrano. 2010. Eimeria macusaniensis associated lesions in neonate alpacas dying from enterotoxemia. Veterinary Parasitology 168 (1-2): 116-120. http://dx.doi.org/http://dx.doi.org/10.1016/j.vetpar.2009.10.010.

Ruthsatz, B. 2012. Vegetation and ecology of the high Andean peatlands of Bolivia. Phytocoenologia 42 (34): 133-179. http://dx.doi.org/10.1127/0340-269x/2012/0042-0535.

Salva, B. K., J. M. Zumalacarregui, A. C. Figueira, M. T. Osorio, and J. Mateo. 2009. Nutrient composition and technological quality of meat from alpacas reared in Peru. Meat Science 82 (4): 450-455. http://dx.doi.org/10.1016/j.meatsci.2009.02.015.

San Martin, F., and F. C. Bryant. 1989. Nutrition of domesticated South American llamas and alpacas. Small Ruminant Research 2 (3): 191-216. http://dx.doi.org/http://dx.doi.org/10.1016/09214488(89)90001-1.

Scott, D. W., J. W. Vogel, R. I. Fleis, W. H. Miller, and M. C. Smith. 2011. Skin diseases in the alpaca (Vicugna pacos): a literature review and retrospective analysis of 68 cases (Cornell University 19972006). Veterinary Dermatology 22 (1): 2-16. http://dx.doi.org/10.1111/j.1365-3164.2010.00918.x.

Sumar, J. B. 1996. Reproduction in Ilamas and alpacas. Animal Reproduction Science 42 (1-4): 405-415. http://dx.doi.org/http://dx.doi.org/10.1016/0378-4320(96)01538-2.

Sumar, J. B. 2013. Embryo transfer in domestic South American camelids. Animal Reproduction Science 136 (3): 170-177. http://dx.doi.org/10.1016/j.anireprosci.2012.10.029.

Thomas, S. M., and E. R. Morgan. 2013. Effect on performance of weanling alpacas following treatments against gastro-intestinal parasites. Veterinary Parasitology 198 (1-2): 244-249. http://dx.doi.org/http://dx.doi.org/10.1016/j.vetpar.2013.08.010.

Tibary, A., and J. Vaughan. 2006. Reproductive physiology and infertility in male South American camelids: A review and clinical observations. Small Ruminant Research 61 (2-3): 283-298. http://dx.doi.org/http://dx.doi.org/10.1016/j.smallrumres.2005.07.018.

Vaughan, J. 2011. Ovarian function in South American camelids (alpacas, Ilamas, vicunas, guanacos). Animal Reproduction Science 124 (3-4): 237-243. http://dx.doi.org/http://dx.doi.org/10.1016/j.anireprosci.2010.08.031.

Vaughan, J. L., and A. Tibary. 2006. Reproduction in female South American camelids: A review and clinical observations. Small Ruminant Research 61 (2-3): 259-281. http://dx.doi.org/http://dx.doi.org/10.1016/j.smallrumres.2005.07.015.

Wernery, U., and J. Kinne. 2013. Tuberculosis in camelids: a review. Rev. sci. tech. Off. int. Epiz. 31 (3): 899-906. 
Wheeler, J. C. 1995. Evolution and present situation of the South American camelidae. Biological Journal of the Linnean Society 54 (3): 271-295. http://dx.doi.org/http://dx.doi.org/10.1016/00244066(95)90021-7.

Whitehead, C. E., and D. E. Anderson. 2006. Neonatal diarrhea in Ilamas and alpacas. Small Ruminant Research 61 (2-3): 207-215. http://dx.doi.org/http://dx.doi.org/10.1016/j.smallrumres.2005.07.012.

Williams, S. H., J. Sidote, and K. K. Stover. 2010. Occlusal Development and Masseter Activity in Alpacas (Lama pacos). Anatomical Record-Advances in Integrative Anatomy and Evolutionary Biology 293 (1): 126-134. http://dx.doi.org/10.1002/ar.21016.

Wilson, D.E. and Reeder, D. M. (ed.). 2005: Mammal Species of the World. A Taxonomic and Geographic Reference. Third edition, Vol. 1-2, xxxv + 2142 pp., John Hopkins University Press, Baltimore.

Wuliji, T. 2011. "Fibre production and fibre characteristics of alpacas farmed in United States." In Fibre production in South Amercan camelids and other fibre animals, edited by M.A.; Cutiérres PérezCabal, J.P.; Cervantes, I.; Alcalde, M.J., 65-72. Wageningen Academic Publishers.

Xhonneux, I. 2010. Parasieten bij de lama in belgié. 


\section{Bijlage 1 Besluit Houders van Dieren: aanwijzing productiedieren}

\section{Besluit Houders van Dieren, Artikel 2.1. Aanwijzing productiedieren}

Als diersoorten of diercategorieën als bedoeld in artikel 2.3, tweede lid, van de wet worden aangewezen de diersoorten en diercategorieën die worden genoemd in bijlage II bij dit besluit.

\section{Bijlage II. als bedoeld in artikel 2.1 van het Besluit houders van dieren}

Aangewezen soorten en categorieën van in Nederland te houden dieren met het oog op de productie van producten die van die dieren afkomstig zijn.

\section{SOORTEN}

Van de klasse Mammalia (Zoogdieren):

Oryctolagus cuniculus (Konijn)

Rattus norvegicus (Bruine rat)

Mus musculus (Tamme muis)

Cavia porcellus (Cavia)

Mesocricetus auratus (Goudhamster)

Meriones unguiculatus (Gerbil)

Mustela vison (Nerts)

Equus caballus (Paard)

Equus asinus (Ezel)

Sus scrofa (Varken)

Capra hircus (Geit)

Bos taurus (Rund)

Bubalus bubalis (Waterbuffel)

Cervus dama dama (Damhert)

Cervus elaphus (Middeneuropees edelhert)

Ovis aries (Schaap) 


\section{Bijlage 2 Toetsingskader voor het verlenen van ontheffing voor diersoorten die niet bij algemene maatregel van bestuur t.b.v. artikel 34 GWWD zijn aangewezen (RDA, 2006)}

Informatie dient te worden verstrekt op de volgende punten:

1. Biologische karakteristieken van de diersoort

2. Algemene informatie met betrekking tot het houden van de betreffende diersoort

3. Specifieke welzijnseisen met betrekking tot het houden van de betreffende diersoort

- Huisvestingseisen voor de betreffende diersoort: grondoppervlak, temperatuur, milieukwaliteit etc.

- Voer en voedermethodieken

- Bezettingsgraad

- Specifieke behandelingsmethode( $n$ )

- Dodingsmethode(n)

- Biotechnologische handeling(en)

- Preventieve en curatieve diergeneeskundige zorg

- Wijze waarop met nakomelingen wordt omgegaan

- Overige soortspecifieke eisen

4. Doel waartoe de diersoort gehouden wordt

- Doel waartoe de diersoort worden gehouden

- Handelingen die met of aan de diersoort zullen worden verricht: handling, transport, handelingen met betrekking tot de reproductie

5. Ervaringen van elders met het houden van de betreffende diersoort

Uit de informatie dient te blijken:

1. De diersoort geschikt is als productiedier

2. Dat op geen van bovengenoemde punten onaanvaardbare gezondheids-en welzijnsproblemen optreden bij het houden van de betreffende diersoort. Dit dient te worden aangetoond met behulp van de volgende positieve en negatieve zoötechnische parameters:

- Normaal en afwijkend gedrag

- (zelf-) Beschadigend gedrag

- Eetlust

- Voortplanting

- Groei

- Mortaliteit

- Vóórkomen van ziekten

3. Op welke wijze op bovengenoemde punten in de praktijk invulling zal worden gegeven aan het managen van het houden van de betreffende diersoort 


\section{Bijlage 3 Definitie Ernst, Duur en Omvang uit Ongeriefanalyse}

Bron: Leenstra et al, 2009

\begin{tabular}{|c|c|c|c|}
\hline & 0 & 1 & 2 \\
\hline Label Ernst & Dier ervaart geen ongerief & Dier ervaart lichte vorm van ongerief & Dier ervaart ernstige mate van ongerief \\
\hline $\begin{array}{l}\text { Natuurlijk gedrag en } \\
\text { gedragsproblemen } \\
\text { (1.1) }\end{array}$ & $\begin{array}{l}\text { Geen onthouding van } \\
\text { aangeboren en/of aangeleerde } \\
\text { behoefte }\end{array}$ & $\begin{array}{l}\text { Onthouding van aangeboren en/of aangeleerde behoefte niet resulterend in } \\
\text { gedragsstoringen (bv geen gedragssynchronisatie mogelijk) }\end{array}$ & $\begin{array}{l}\text { Onthouding aangeboren en/of aangeleerde behoefte uiteindelijk } \\
\text { resulterend in afwijkend, omgericht, compensatie of inhaalgedrag } \\
\text { (bv stereotypieen) }\end{array}$ \\
\hline Sociaal gedrag (1.2) & & $\begin{array}{l}\text { Interventies in de sociale situatie zonder zichtbare gevolgen: 1) verstoring } \\
\text { sociale structuur resulterend in kortdurend agonistisch gedrag zonder } \\
\text { verwondingen; 2) tijdelijk gedeeltelijk onthouden van sociaal contact (bv } \\
\text { fixatie binnen de groep) }\end{array}$ & $\begin{array}{l}\text { Ingrijpende interventies in de sociale situatie: 1) resulterend in } \\
\text { gedragsproblemen (bv stereotiep gedrag, emstig agonistisch } \\
\text { gedrag en verwondingen in groepen), 2) resulterend in chronische } \\
\text { stress (bv langdurig onthouden van sociaal contact), 3) resulterend } \\
\text { in tijdelijk emstige angst en stress (bv spenen; afzondering voor } \\
\text { medische ingreep of partus) }\end{array}$ \\
\hline Algehele angst (1.3) & & Milde angst en stress veroorzaakt door soortgenoten en/of bedrifsvoering & $\begin{array}{l}\text { Ernstige angst en stress veroorzaakt door soortgenoten en/of } \\
\text { bedrifssoering }\end{array}$ \\
\hline $\begin{array}{l}\text { Angst voor mensen } \\
\text { (1.4) }\end{array}$ & & Milde angst en stress veroorzaakt door mens-dier interactie & Ernstige angst en stress veroorzaakt door mens-dier interactie \\
\hline Ziekte (2.1) & & $\begin{array}{l}\text { Ziekteverschijnselen die het normale functioneren niet of nauwelijks } \\
\text { beinvloeden }\end{array}$ & $\begin{array}{l}\text { Ziekteverschijnselen die normaal functioneren ernstig bemoeilijken } \\
\text { (mogelijke verschijnselen: koorts, infecties, verlaagde weerstand, } \\
\text { pijn, gewichtsvermindering, algehele malaise etc.) }\end{array}$ \\
\hline Verwondingen (2.2) & & Verwondingen zonder merkbare gedragsveranderingen & Verwondingen met merkbare gedragsveranderingen \\
\hline Ingrepen (2.3) & $\begin{array}{l}\text { Leven met de ingreep zonder } \\
\text { merkbare gedragsveranderingen }\end{array}$ & $\begin{array}{l}\text { Leven met de ingreep waarbij het dier zijn gedrag probleemloos kan } \\
\text { aanpassen }\end{array}$ & $\begin{array}{l}\text { Leven met de ingreep waarbij het dier zijn gedrag niet zonder } \\
\text { problemen kan aanpassen }\end{array}$ \\
\hline Ingrepen (2.3) & & $\begin{array}{l}\text { Uitvoeren van de ingreep zonder merkbare gedragsveranderingen; ingreep } \\
\text { waarvan onbekend is het dier ongerief ondervindt }\end{array}$ & Uitvoeren van de ingreep met merkbare pijnreactie \\
\hline $\begin{array}{l}\text { Rust- en ligcomfort } \\
\text { (3.1) }\end{array}$ & & $\begin{array}{l}\text { Gebrek aan voldoende en/of geschikte rustplaatsen, niet resulterend in } \\
\text { fysieke problemen (bv doorligplekken, pootproblemen door overbelasting) } \\
\text { enlof gedragsstoringen (bv onrust en conflicten) }\end{array}$ & $\begin{array}{l}\text { Gebrek aan voldoende en/of geschikte rustplaatsen resulterend in } \\
\text { fysieke (bv doorligplekken, pootproblemen) en/of gedragsstoringen }\end{array}$ \\
\hline Bewegingsgemak (3.2) & & $\begin{array}{l}\text { Beperking van het bewegingsgemak zonder merkbare } \\
\text { gedragsveranderingen of verwondingen }\end{array}$ & $\begin{array}{l}\text { Beperking van het bewegingsgemak resulterend in verwondingen } \\
\text { en/of gedragsmatig niet kunnen aanpassen }\end{array}$ \\
\hline Thermocomfort (3.3) & & $\begin{array}{l}\text { Omgevingstemperatuur buiten de comfortzone maar binnen de } \\
\text { thermoneutrale zone }\end{array}$ & Omgevingstemperatur buiten de thermoneutrale zone \\
\hline Voeding (4.1) & & $\begin{array}{l}\text { Ontoereikende rantsoensamenstelling niet resulterend in } \\
\text { gezondheidsproblemen en/of gedragsstoringen }\end{array}$ & $\begin{array}{l}\text { Ontoereikende rantsoensamenstelling resulterend in } \\
\text { gezondheidsproblemen en/of gedragsstoringen }\end{array}$ \\
\hline Vochtverstrekking (4.2) & & $\begin{array}{l}\text { Ontoereikende vochtverstrekking niet resulterend in } \\
\text { gezondheidsprobelemen en/of gedragsstoringen }\end{array}$ & $\begin{array}{l}\text { Ontoereikende vochtverstrekking resulterend in } \\
\text { gezondheidsprobelemen en/of gedragsstoringen }\end{array}$ \\
\hline Label Duur & $\begin{array}{l}\text { Momentaan (<1\% van duur van } \\
\text { de periode/productiefase) }\end{array}$ & Kortdurend, incidenteel ( 1 - $10 \%$ van duur van de periode/productiefase) & $\begin{array}{l}\text { Chronisch, regelmatig, structureel (> } 10 \% \text { van duur van de } \\
\text { periode/productiefase) }\end{array}$ \\
\hline Label Omvang & $\begin{array}{l}<1 \% \text { van de populatie waarop } \\
\text { van toepassing ondervindt } \\
\text { ongerief (code } 0 / 1 / 2 \text { ) }\end{array}$ & $\begin{array}{l}1-10 \% \text { van de populatie waarop van toepassing ondervindt ongerief (code } \\
0 / 1 / 2)\end{array}$ & $\begin{array}{l}>10 \% \text { van de populatie waarop van toepassing ondervindt ongerief } \\
\text { (code 0/1/2) }\end{array}$ \\
\hline
\end{tabular}




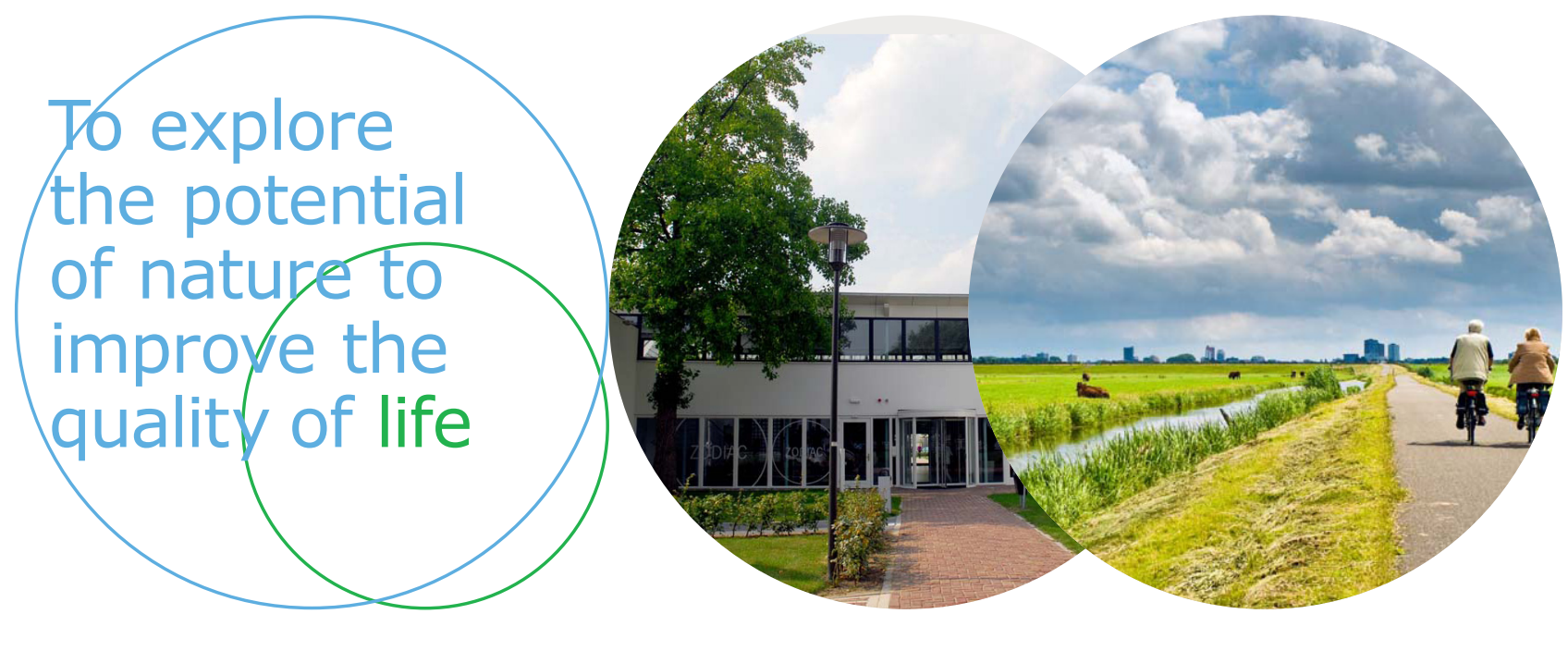

Wageningen Livestock Research Postbus 338

Wageningen Livestock Research ontwikkelt kennis voor een zorgvuldige en $6700 \mathrm{AH}$ Wageningen

T 0317483953

E info.livestockresearch@wur.nl www.wur.nl/ livestock-research renderende veehouderij, vertaalt deze naar praktijkgerichte oplossingen en innovaties, en zorgt voor doorstroming van deze kennis. Onze wetenschappelijke kennis op het gebied van veehouderijsystemen en van voeding, genetica, welzijn en milieu-impact van landbouwhuisdieren integreren we, samen met onze klanten, tot veehouderijconcepten voor de $21 \mathrm{e}$ eeuw.

De missie van Wageningen University \& Research is 'To explore the potential of nature to improve the quality of life'. Binnen Wageningen University \& Research bundelen 9 gespecialiseerde onderzoeksinstituten van Stichting Wageningen Research en Wageningen University hun krachten om bij te dragen aan de oplossing van belangrijke vragen in het domein van gezonde voeding en leefomgeving. Met ongeveer 30 vestigingen, 6.500 medewerkers en 10.000 studenten behoort Wageningen University \& Research wereldwijd tot de aansprekende kennisinstellingen binnen haar domein. De integrale benadering van de vraagstukken en de samenwerking tussen verschillende disciplines vormen het hart van de unieke Wageningen aanpak. 